\title{
Effects of Positive Practices on Organizational Effectiveness
}

\author{
Kim Cameron, \\ Ross School of Business \\ University of Michigan \\ Ann Arbor, Michigan 48109 \\ Kim cameron@umich.edu \\ Carlos Mora \\ Determinant LLC \\ Ann Arbor, Michigan 48104 \\ carlos.e.mora@gmail.com \\ Trevor Leutscher \\ Determinant LLC \\ Ann Arbor, Michigan 48104 \\ tleutscher@comcast.net \\ Margaret Calarco \\ School of Nursing and University of Michigan Health Centers \\ University of Michigan \\ 'Ann Arbor, Michigan 48109 \\ mcalarco@umich.edu
}

This study is sponsored by the Health Resources and Services Administration

Grant \#D66HP05244

"Nurse Education, Practice, and Retention: Enhancing Patient Care Delivery Systems"

Dr. Margaret Calarco, Principal Investigator

and by the Center for Positive Organizational Scholarship

Ross School of Business

University of Michigan

Please do not reproduce without permission. 


\section{Effects of Positive Practices on Organizational Effectiveness}

Emphasis on positivity in organizations in increasing, but the importance and credibility of a positive approach to change—exemplified by Positive Organizational Scholarship—remains controversial. More empirical evidence is needed showing that positive practices in organizations produce desirable changes in organizational effectiveness. Two studies-one in financial services and one in the health care industry —are reported which investigate the link between positive practices and indicators of organizational effectiveness. A positive practices instrument is developed, and evidence is found that positive practices do, in fact, predict organizational performance. More importantly, improvement in positive practices predicts improvements in certain indicators of effectiveness over time. The results are explained by the inherent amplifying, buffering, and heliotropic effects of positivity in human systems. 


\section{Effects of Positive Practices on Organizational Effectiveness}

Increasing attention is being given to the term "positive" in organizational studies, and positivity has become a popular topic with consultants, self-help advocates, and change agents. This term, however, has created controversy among organizational scholars and has spawned skeptics as well as advocates. The term "positive" is accused of a potentially restrictive connotation and values bias (George, 2004; Fineman, 2006) and is criticized as implying that most organizational science is negative, that an ethnocentric bias is represented, that a narrow moral agenda is being pursued, or that non-rigorous concepts are being espoused without theoretical grounding (Hackman, 2008). The term has been credited, on the other hand, with expanding and enriching the domain that explains performance in organizations and with opening up, rather than restricting, organizational science (Dutton \& Glynn, 2007; Harter, Schmidt, \& Keyes, 2002; Spreitzer, Sutcliffe, Dutton, Sonenshein, \& Grant, 2005).

The field of Positive Organizational Scholarship (POS) was developed to study positive outcomes, practices, and attributes of organizations and their members. POS aims to reveal positive capabilities and activities that lead to flourishing in organizations (Cameron, Dutton, \& Quinn, 2003). The importance and credibility of this field of study, however, at least partly depends on the relationships between positive practices and organizational performance and change. POS researchers advocate for including positive phenomena in organizational science because, ostensibly, they account for variance in performance that may otherwise be overlooked (Carson \& Barling, 2008; Roberts, 2006; Dutton \& Sonenshein, 2007). Some challenge this claim as being overly optimistic and more typical of aspiration than realism (Hackman, 2008; Fineman, 2006). Unfortunately, investigations of positive phenomena in organizational science are still relatively sparse and under-developed, and few studies have examined systematically the effects of positive practices on organizational performance (Caza \& 
Cameron, 2008) and, especially, organizational change. The argument that POS has scientific validity in organizational studies is still in need of empirical support.

This study addresses the dearth of research on the impact of positive practices on organizational effectiveness and change. It aims to examine directly the criticism that, thus far, empirical evidence that positivity is advantageous is lacking (Hackman, 2008), so claims regarding the importance of positivity in organizations are over-exaggerated. Investigations in two different industries are reported which examine the relationships between positive practices and organizational outcomes.

To be sure, ample research has been conducted on positive factors such as positive affect, subject well-being, organizational citizenship and prosocial behavior, positive identity, engagement, psychological capital, and satisfaction (Harter, Schmidt, \& Keyes, 2002; Luthans, Youssef, \& Avolio, 2007). Investigations of organizational citizenship behavior (OCB), for example, have uncovered relationships between OCB and with sales performance or human resource practices (Podsakoff \& Mackenzie, 1994; Sun, Aryee, \& Law, 2007). Most of the outcomes in these studies, however, focus on the individual level of analysis rather than on organizational performance (Moore \& Beadle, 2006). As depicted in Figure 1, relationships between positivity and individual outcomes have been verified but not relationships with organizational outcomes. That is, evidence exists that positive practices (e.g., respectful treatment, personal development) produce positive affect in employees (e.g., satisfaction, wellbeing), which produces positive individual behavior (e.g., retention, engagement) which, in turn, produces organizational effectiveness (e.g., profitability, productivity) (see Lyubomirsky, King, \& Diener, 2005). The last link in this chain is, as yet, however, under-examined. The connection between positive practices and organizational effectiveness needs empirical confirmation (Chun, 2005; Wright \& Goodstein, 2007).

Figure 1 about here 


\section{Positive Practices}

In order to find evidence that positive practices impact organizational outcomes, the meaning of the term "positive" must be clarified. In fact, the tentativeness regarding the link between positive practices and organization performance exists at least partly because of the ambiguity surrounding this term. Past literature converges around three connotations of the concept of positive in organizational science. One focuses on extraordinarily positive outcomes, or positively deviant performance (Spreitzer \& Sonenshein, 2004). This means that outcomes are investigated which dramatically exceed common or expected performance. Investigations of spectacular results, surprising outcomes, and unanticipated achievements have been the focus of several investigations (e.g., Cameron \& Lavine, 2006; Gittell, Cameron, Lim, \& Rivas, 2006; Hess \& Cameron, 2006; Baker \& Bunderson, 2005), each treating "positive" as synonymous with exceptional performance. Positive deviance, in other words, extends beyond achieving effectiveness or ordinary success in that it represents "intentional behaviors that depart from the norm of a reference group in honorable ways" (Spreitzer \& Sonenshein, 2003:209).

A second area of convergence focuses on an affirmative bias, or on strengths, capabilities, and possibilities rather than problems, threats, and weakness. This focus emphasizes positive energy, positive climate, positive relationships, positive communication, and positive meaning in organizations (Baker, 2000; Cameron, 2008), as well as the value embedded in obstacles and challenges (Losada \& Heaphy, 2004; Weick, 2003). It includes appreciative inquiry (Cooperrider \& Srivastava, 1987), positive energy (Baker, Cross, \& Wooten, 2003), and strengths-based assessments (Clifton \& Harter, 2003). It does not exclude consideration of negative events but, rather, incorporates them in accounting for positive outcomes (Dutton, Worline, Frost, \& Lilius, 2006; Bagozzi, 2003).

A third area of convergence relates to the concepts of virtuousness and eudemonism (Peterson \& Seligman, 2004; Cameron, Bright, \& Caza, 2004). POS is based on a 
eudemonic assumption-i.e., that an inclination exists in all human systems toward goodness for its intrinsic value (Aristotle, Metaphysics; Dutton and Sonenshein, 2007). Whereas debate has occurred regarding what constitutes goodness and whether universal human virtues are identifiable, all societies and cultures possess catalogues of traits that they deem virtuous, or that represent the highest aspirations of human kind (Peterson \& Seligman, 2004; ComteSponville, 2001). POS examines the development of and effects associated with virtuousness and eudemonism (Cameron, 2003; Bright, Cameron, \& Caza, 2006; llies, Nahrgang, \& Morgeson, 2007). This is consistent with what Aristotle labeled goods of first intent—or "that which is good in itself and is to be chosen for its own sake" (Metaphysics XII, p. 3). Virtuousness is inherently valuable, aside from any benefit that may accrue, so its association with other outcomes may be considered superfluous. Nevertheless, studies of virtuousness and its impact on individual and organizational performance have begun to appear in the scholarly literature (Bright, 2006; Bright, Cameron, \& Caza, 2006; Cameron, 2003; Chun, 2005; Marotto, Roos, \& Victor, 2007), and some convergence in POS is occurring regarding the term "positive" being indicated by virtuousness and eudemonism.

The investigations reported here attempted to incorporate all three connotations of positive in that they sought to examine organizational practices-i.e., behaviors, techniques, routines-that represent positively deviant (i.e., unusual) practices, practices with an affirmative bias, and practices that connote virtuousness and eudemonism in organizations. The intent is to examine empirically the link between positive practices and organizational effectiveness as depicted in Figure 1.

\section{Two Investigations}

This paper reports two studies that explore the relationships between positive practices and various measures of organizational effectiveness. The key questions being investigated are: (1) Do positive practices in organizations impact organizational performance? Or, stated 
differently, Does positivity foster organizational effectiveness? (2) If evidence exists for question 1, Which positive practices are most strongly associated with elevated performance? Evidence exists that positivity and organizational outcomes are related (Cameron, Bright, \& Caza, 2004; Losada \& Heaphy, 2004), but not enough information is available to formulate precise hypotheses about which specific positive practices relate to which specific indicators of effectiveness.

Two studies were conducted in different types of organizations. Study 1 was conducted in 40 business units in the financial services industry, and Study 2 was conducted in 29 nursing units in the health care industry. The financial services industry was selected because positive practices and organizational virtuousness are not often associated with financial service organizations, which stereotypically are dominated by monetary concerns and a profit motive. Health care, on the other hand, is stereotypically concerned with compassionate care and human service. The question of interest was whether positive practices could be identified and investigated in these markedly different industry types.

\section{Assessing Positive Practices}

Unfortunately, no assessment instrument available claims to capture positively deviant, affirming, and virtuous practices at the organization level of analysis (Chun, 2005; Wright \& Goldstein, 2007). Numerous lists of virtuous behaviors have been published, but all of them were derived from lists of personality factors and individual traits (e. g., Moberg, 1999; Solomon, 1992; Murphy, 1999; Shanahan \& Hyman, 2003; Chun, 2005), and they do not apply to organizational practices. Consequently, a new assessment instrument was needed. Using procedures similar to those employed by Peterson and Seligman (2004) in producing lists of universal character traits and virtues, and by Brown (1991) in producing a list of human universals, positive organizational practices were nominated by senior faculty members in the University of Michigan's Center for Positive Organizational Scholarship based on prior research 
${ }^{(1)}$, literature reviews, and observations in organizations. Practices were defined as collective behaviors or activities sponsored by and characteristic of an organization. They were not indicative of emotions or climate, therefore, but they were behavioral in their orientation.

No overarching theory was used to derive this list of positive practices; rather they were identified because they had appeared in prior research, they represented behavioral practices or activities, and they possessed at least one of the three connotations of positive mentioned above. The resulting list of positive practices was not comprehensive, but it represented an extensive inventory of the behaviors and attributes assumed to characterize positivity in organizations. The studies reported here are exploratory, therefore, in the sense that no previous investigations have examined positive practices in combination nor has their connection to organizational performance been explored.

The survey initially consisted of 114 Likert-type items representing desirable, positivelyfocused behaviors, techniques, or routines. The survey instrument was analyzed using exploratory factor analysis in order to identify the underlying structure. Using data sets from both industry studies ${ }^{(2)}$, an underlying structure with six stable dimensions emerged which reduced the number of relevant items to 29. That is, the same 6 positive practice dimensions were reliably reproduced in each data set and in each administration of the survey over multiple years. These six factors, therefore, were the ones used to predict organizational effectiveness in both studies ${ }^{(3)}$. Table 1 provides a brief description of each positive practice dimensions, and Table 2 reports the descriptive statistics, inter-item correlations, and Cronbach's Alpha statistics. Appendix A reports factor loadings using Varimax rotation for three different data sets.

Table 1 about here

Table 2 about here

Items in the survey asked respondents to describe the behaviors, practices, or activities of the organization and its employees, not individual attitudes or attributes. Therefore, the 
organization is the unit of analysis, not the individual respondent. Attributes and activities of organizations are assessed, not behaviors or traits of individual respondents.

\section{Study 1 Methods}

The first study was conducted in the financial services industry because of its focus on short-term monetary returns, financial trading, high-pressure climates, and objective outcomes (Burrough \& Helyar, 1990; Jensen, 2002; Korten, 2001; McLean \& Elkind, 2003). Virtuousness and positive practices are not typically described as dominant attributes of organizations in this industry. Consequently, if an effect of positive practices on performance is uncovered in an industry that does not usually emphasize positive practices, it is expected that clearer effects might be typical of organizations in more compatible environments. This first study in financial services was undertaken, therefore, as a relatively conservative test of the effects of positive practices on organizational performance.

To address the research questions, 40 business units within a large northeast financial services company were investigated. This company embarked on a systematic effort to incorporate positive practices into its corporate culture in early 2005 when the CEO declared that POS would guide the strategic direction of the firm. A variety of initiatives were undertaken to integrate positive practices into the company's businesses. The processes by which these initiatives were undertaken included senior executive retreats to explain positive principles, establishing formal positive-related goals, creating a nine-person change team charged with assisting business units to develop a positive culture, and refocusing the incentive system toward positive practices (Vanette \& Cameron, 2008). ${ }^{(4)}$

The company's 40 business units consisted of customer service units, support service units, investment business units, business analysis units, distribution units, marketing units, established and emerging market business units, and the senior executive team. Unfortunately, only six of the business units had profit-and-loss (P\&L) responsibility and therefore generated a 
financial return. Consequently, financial performance information was available for only six of the units. This created a problem of restricted variance in a key outcome variable and limited the ability to predict organizational financial performance, as explained below. Appendix B lists the 40 business unit names, with appropriate alterations made to preserve confidentiality. Total employment in the firm was approximately 2386 during the time of the study in 2005 and 2006.

The study examined the extent to which positive practices affected key bottom-line outcomes that were selected by the company to be vital to its effectiveness. In addition to information on positive practices, several types of outcome measures were obtained as part of Study 1:

- $\quad$ Positive practices (the six dimensions of the Positive Practices Survey)

- $\quad$ Employee turnover (from company records)

- $\quad$ Organizational climate (the firm's Employee Opinion Survey-EOS)

- $\quad$ Financial performance outcomes (from internal firm sources)

- $\quad$ Senior executive rankings of unit effectiveness (for the six P\&L businesses)

Positive Practices. The Positive Practices Survey was administered to all employees in the company by means of the firm's internal electronic communication system. Respondents completed the survey on-line, then submitted their completed surveys to an independent data analyst who compiled the results. The survey was administered in the summer of 2005 and the response rate was 1989 or 83 percent. Respondents from each of the 40 business units were represented in the data set. The highest POS score aggregated at the business unit level was 4.52 on a 5-point Likert scale, and the lowest was 3.42. The average score was 3.89 with a standard deviation of .23 .

Employee Turnover. Voluntary employee turnover rates were obtained for each of the 40 businesses in the company for the period of the study. Business unit turnover ranged between 0 and 21.9 percent, indicating that some units maintained high employee loyalty and stability whereas others experienced difficulty retaining their employees. 
Organizational Climate. An independent company administers an Employee Opinion Survey (EOS) in this financial services company on an annual basis. The raw data from the 2006 survey were made available to the researchers by the company. The response rate was 1766 employees or 74 percent. This survey collects data on nine factors:

Employee retention (e.g., "I have seriously considered leaving this firm in the last six months") Connection to the company's mission (e.g., "This company is making changes to compete effectively ... Senior leaders have clear vision ... and know what's on employees minds")

Personal influence (e.g., "My work gives me a feeling of accomplishment ... makes use of my skills ... provides me with necessary training")

Managerial effectiveness (e.g., "My supervisor effectively communicates ... works effectively ... inspires the best ... responds appropriately")

Work environment (e.g., "I am not afraid to say what I think to anyone in this organization")

Employer of choice (e.g., "Satisfaction with the company ... Recommend the firm as a place to work")

Work-life balance (e.g., "We have necessary resources . . I l am satisfied with level of work and personal life balance ... job allows flexibility to meet personal needs")

Reward system (e.g., "People are rewarded according to job performance ... I feel my pay is fair")

Ethics (e.g., "I feel pressured to compromise the company's standards of ethical conduct").

These items all have Likert-type response scales, and completed surveys were submitted to the consulting firm for analysis.

Financial Performance. Seven measures of financial performance were obtained from the organization. These included average assets, sales, cash outs (removal of funds from the investment portfolio of the company), cash flow, revenues, expenses, and ROI for the end of the year 2006. Because of legal constraints—namely, that the Securities and Exchange 
Commission prohibits confidential financial data from being shared in its raw form with outsiders - the data were provided in a coded form. This coding scheme for the six P\&L business units was explained in the following way.

The financial performance of each business unit was compared to the overall average performance for the entire company. Units achieving above average performance were deemed more successful, whereas units achieving below average performance were deemed less successful. Financial data were provided to the researchers as a percentage of performance relative to the company's average as well as in the form of a rating of each financial indicator. A rating of ' 1 ' indicated that the unit performed three standard deviations below average. A rating of ' 2 ' indicated performance two standard deviations below average. A ' 3 ' meant performance one standard deviation either way_-plus or minus_from the company's average. A rating of ' 4 ' indicated two standard deviations above the average. A ' 5 ' indicated three standard deviations above the average. Appendix $C$ provides the percent deviations and ratings received by each of the six P\&L business units.

The reduction in variance that resulted from data coding represents another conservative constraint on the study. Significant relationships between positive practices and financial performance are less likely to emerge when the amount of variance in the data has been constricted. Consequently, the likelihood of uncovering significant relationships between positive practices and organizational performance is substantially reduced due to restricted variance.

Expert Ratings. Three senior executive officers in the company were asked to rank order the six P\&L business units according to two general criteria. First was the extent to which the business units were "effective," meaning the extent to which the unit achieved its goals by the end of 2006 . The second criterion was the extent to which employees were highly "engaged," or the extent to which the business unit possessed a vibrant working climate at the end of 2006. These rankings were subjective ratings by knowledgeable experts regarding the 
performance of these units, apart from objective financial or climate survey data. Units were compared to one another and ranked from 1 to 6 by the executives. These data provide the subjective impressions of executive-level decision makers who have responsibility for making resource allocation decisions in the firm. These senior executive evaluations are important because they impact the amount of future financial and human resources that units are able to acquire.

\section{Study 1 Results}

Measures of positive practices in 2005 were used to predict outcomes in 2006, so a oneyear lag suggests that indicators of effectiveness are not determining the scores on the positive practices survey. To ensure that it was appropriate to aggregate individual responses at the organization level, tests were conducted to compare within-unit ratings with between-unit scores (Schneider \& Bowen, 1985). Results indicated a between MSE=1.545, within MSE=.391, Ftest $=3.948$, degrees of freedom $=39,10636, p<0.001$. Aggregating individual responses to indicate an organizational level measure, therefore, is appropriate.

Positive Practices and Employee Turnover. The relationships between employee turnover and two predictors—positive practices and employee climate (EOS)—were examined. If positive practices are an important predictor of organizational effectiveness, they should show a strong, negative association with voluntary turnover. In addition, the climate (EOS) survey instrument asked a direct question about employees' propensity to leave the company, so a business' EOS scores were expected to be strongly associated with the extent to which employees voluntarily left. Turnover rates among these business units ranged from zero to 21.9 percent with most units reporting low turnover, so restriction in variance reduced the probability of statistically significant results. Nevertheless, the correlation between turnover and positive practices is $r=-.21$, and the correlation between turnover and EOS (intent to leave) is $r=-.34^{(5)}$. These results suggest that when employees indicate an intention to leave the firm on the EOS 
instrument, they tend to follow through. More importantly, when positive practices are in place, employees tend to stay with the firm.

Positive Practices and Organizational Climate. Of the nine climate factors assessed on the EOS, a statistically significant association between positive practices and climate was found with three of them-Work Environment, Managerial Effectiveness, and Employee Retention. Businesses with higher scores on positive practices experienced a better work environment, more effective relationships with management, and greater numbers of employees intending to stay with the firm. The effects of positive practices on the other dimensions of climate were in a positive direction, but they did not attain statistical significance.

Specifically, higher levels of positive practices in businesses did not reach statistical significance regarding the units' missions, the personal influence of employees, work-life balance, ethics, the reward system, or being an employer of choice. With the exception of the last indicator, it is reasonable to assume that positive practices would not significantly alter these factors in a business. The missions, ethics, reward systems, work-life balance, and influence achieved by employees are not transparently connected to positive practices-these factors exist regardless of positive practices-as compared to overall work climate, managerial effectiveness, and employee retention.

Moreover, certain climate factors—e.g., ethics, reward systems—were measured by only one or two survey items, and in the case of the ethics dimension, the favorability of the ratings was above 90 percent. Hence, restricted variance in responses makes significant relationships very unlikely. Figure 2 provides the relationships between positive practices and each climate factor.

Figure 2 about here

Positive Practices and Financial Performance. Because the financial data were provided in coded rather than raw form, analyses had to be conducted via rank-order correlations among 
the six P\&L business units. More powerful parametric statistical analyses could not be conducted. Nevertheless, the correlation between the aggregated positive practice score for each unit and the aggregation of the six measures of financial performance is $r=.54$, significant at the $p<.05$ level with only six degrees of freedom. The one year lag in positive practices compared to financial performance provides support for the notion that positive practices are predicting financial results rather than the reverse. Positive practices appear to be important contributors to organizational effectiveness as measured by financial performance.

Positive Practices and Executive Judgments. Three senior executives ranked the six P\&L businesses according to their perceptions of unit effectiveness (i.e., goal accomplishment) and employee engagement (i.e., an enriching and satisfying work climate). The intercorrelations among these executives' rankings is $r=.92$ for effectiveness and $r=.79$ for engagement, indicating that a relatively high degree of consistency is typical of their evaluations. An analysis was conducted to determine whether financial performance or positive practices best predict senior executives' rankings of these indicators of effectiveness. The question was: "When executives form impressions of the relative effectiveness of business units, is financial performance the best predictor of these impressions or are positive practices better predictors?"

The results reveal that positive practices are more predictive of perceived senior executive effectiveness than is financial performance. Correlations are higher when senior executives judged goal accomplishment-a construct with clear quantitative indicators—-than when senior executives judged employee engagement-a construct without clear quantitative indicators. Nevertheless, positive practices are better predictors of senior executive judgments on both criteria of effectiveness than is financial performance. Table 3 reports the results.

Table 3 about here

Caveats. Unfortunately, the restricted variance in financial and expert ranking measures limited the extent to which the relationships with specific positive practices could be examined. 
With an $\mathrm{N}=6$ for financial and expert rankings data and high multicolinearity among the six positive practice dimensions, it was not possible to analyze the individual effects of the different positive practices. In addition, data were collected at a single point in time, and whereas a year time lag was incorporated into the analysis of performance, change scores were not available. A more rigorous analysis of the effects of positive practices would examine whether improvements in positive practices could predict improvements in organizational effectiveness.

Consequently, a second study was conducted to examine more precisely the relationships between positive practices and organizational outcomes, and more specifically, to examine change scores in both positive practices and effectiveness. The findings in financial services organizations provided support for the existence of a positive relationship between overall positive practices and various proxies for organizational effectiveness, but the questions were left unanswered, "Do changes in positive practices lead to changes in organizational performance?' If so, "Which positive practices are most predictive of improved effectiveness?"

\section{Study 2 Methods}

The second study was carried out in 29 nursing units in a large, comprehensive health care system. These units are all inpatient units. Appendix B lists the 29 unit names in Study 2. Nurses provided the survey data in the study and rated the unit in which they worked. Total nursing employment was approximately 3200 during the period of the study -2005 through 2007.

A multi-year research grant through the Health Resources and Services Administration was obtained to fund the implementation of positive practices throughout these 29 nursing units and to assess the extent to which these practices affected indicators of organizational performance. Multi-day sessions were held with the nursing leaders and directors in this health system which exposed them to POS concepts, and day-long implementation sessions were conducted by an external consultant with the 29 nursing units as a follow-up. By the third year 
of the study, all 29 units had been exposed to POS and had held implementation sessions. (See footnote 4)

Over the period of the study, positive practices tended to increase in the 29 units included in the study, but they did not change, or slightly deteriorated, in the non-involved units. Figure 3 illustrates these results. Differences between 2005 and 2007 are significant at the p $<.001$ level. Uncovering statistically significant differences among the nursing units included in the study was made more difficult, of course, because of a restriction in the range of positive practices. Comparing the 29 units that implemented positive practices with units in the same health system that were not included in the study would likely produce more variance and, consequently, the probability of stronger statistically significant relationships. However, performance data were available only for units participating in the study. The analyses in Study 2 , therefore, represent another conservative test of the effects of positive practices on effectiveness by analyzing only units exposed to positive practices.

Figure 3 about here

Several indicators of performance were obtained for these units. They were identified as among the most important indicators of effectiveness by senior executive officers. They are similar to, but not exactly the same as, the indicators assessed in the financial service industry (6). These indicators included:

- $\quad$ Overall Satisfaction (from organization records)

- $\quad$ Patient Satisfaction with Pain Management (from organization records)

- Willingness to Recommend the Hospital (from on-going nurse evaluations available in organization records)

- Voluntary Employee Turnover (from organization records)

- $\quad$ Overall Organizational Climate (Practice Environment Scale administered by an independent external organization)

- $\quad$ Participation in Hospital Affairs (Practice Environment Scale administered 
by an independent external organization)

- $\quad$ Foundations for Quality Care (Practice Environment Scale administered

by an independent external organization)

- Managers' Support of Nurses (Practice Environment Scale administered

by an independent external organization)

- $\quad$ Resource Adequacy (Practice Environment Scale administered

by an independent external organization)

- $\quad$ Nurse/Physician Relations (Practice Environment Scale administered

by an independent external organization)

Positive Practices. The Positive Practices Survey was administered to the entire nurse population in the organization through the organization's on-line distribution system.

Respondents anonymously completed the survey but did provide the organizational unit in which they were employed. Approximately 33 percent of nurses completed the survey in each of the years in which it was administered. In 2005, 315 nurses responded and in 2007, 442 nurses responded. The highest POS score aggregated at the nurse unit level was 4.47 on a 5point Likert scale, and the lowest was 2.98. The average score was 3.75 with a standard deviation of .72. To ensure that aggregation at the unit level was appropriate, within-unit individual ratings were compared to between-unit ratings. The results confirmed that aggregation was appropriate. (2005: Within MSE=.345, Between MSE=.843, F-test=2.44, degrees of freedom=28,283, $p<.0001$. 2007: Within MSE=-.396, Between MSE=1.305, Ftest $=3.203$, degrees of freedom $=28,408, p<.001$.)

Overall Patient Satisfaction with Pain Management. A Patient Satisfaction Survey was administered to discharged patients on an on-going basis throughout the year by an independent entity. The intent was to regularly monitor patient experiences with the hospital and with the medical care received. Unfortunately, overall patient satisfaction with pain management is not relevant for all organizations in the study (some units did not discharge 
patients), so only about half of the units have scores on these measures. Overall satisfaction scores ranged from 82 to 92 across the 29 units, and pain management scores ranged from 75 to 87 on the 100 -point scale.

Overall Satisfaction and Willingness to Recommend. On an annual basis, nurses rated the extent to which they were satisfied with the health care system and the degree to which they were willing to recommend the hospital as a place where their family members or close friends should come for treatment. This assessment was designed to capture an overall assessment of quality of care, adequacy of resources, nature of the work environment, and the amount of compassionate and caring attention that is available. Only about half the units had data available on this measure, and the range was from 47 to 92 on a 100-point scale.

Employee Turnover. Voluntary turnover rates are collected monthly by the organization, and they ranged between zero and 33 percent across the units. At the beginning of the study in 2005 overall turnover was 10.5 percent and in 2007 it was 9.8 percent, a slight overall decrease. Turnover is affected by a large variety of factors including the economic downturn in the geographic area in which the health system is located, so the probability that positive practices would be powerful enough to overcome these macro-economic factors is small. Turnover was included in Study 2, nevertheless, since it is an important proxy for organizational effectiveness.

Organizational Climate. The health system's central administration distributed a Practice Environment Scale (PES) during 2005 and 2007. This instrument was designed to assess five different aspects of nurses' daily work. The five dimensions include:

Participation in hospital affairs (e.g., "Nurses are involved in the internal governance of the hospital")

Foundations for quality of care (e.g., "An active quality assurance program is utilized") Manager ability, leadership, and support of nurses (e.g., "A supervisory staff is supportive of the nurses")

Staffing and resource adequacy (e.g., "Enough staff is available to get the work done") 
Collegial nurse-physician relations (e.g., "Collaboration between nurses and physicians") In 2005, 747 nurses responded and in 2007, 612 nurses responded. Average scores across the five dimensions were between 2.81 and 2.94 on a 5-point Likert scale.

\section{Study 2 Results}

Figure 3 illustrates that, taken as a whole, units that implemented positive practices tended to improve significantly in their scores over the 2005 to 2007 period, whereas units not exposed to POS did not improve. However, examining each of the 29 units individually revealed that some improved a great deal more than others. This finding led to examining the central questions in Study 2: "Do changes in positive practices over time produce increases in organizational performance?" If so, "Which practices are the most powerful predictors of effectiveness?"

Positive Practices and Organizational Effectiveness. Table 4 reports the mean scores of the units that scored the highest (top quartile) on positive practices compared to units that scored the lowest (bottom quartile). This is one way to examine the effects of positive practices on performance-that is, to examine whether units scoring highest on positive practices were more effective two years later than units that score lowest on positive practices. Limited degrees of freedom again restrict statistical significance, although five of the comparisons approach significance. With the exception of turnover, all mean differences are all in the expected direction. These mean comparisons support the idea that the implementation of aggregated positive practices is associated with achieving higher levels of organizational effectiveness.

Table 4 about here

The more important analyses, however, focused on changes in positive practices and in effectiveness between 2005 and 2007. Table 5 reports the results of the comparisons between 
the units that improved the most (i.e., top quartile) compared to the units that improved the least (i.e., bottom quartile) in positive practices. On each performance indicator, units that improved overall positive practices outperformed units that did not, even when all units were exposed to POS and had attempted to implement positive practices. Limited degrees of freedom inhibited statistically significant differences on most of the comparisons, but the differences in change scores all indicate that when units improved their positive practices, their performance also improved in subsequent years.

\section{Table 5 about here}

In the absence of statistically significant differences, an analysis was conducted following the methods of Harter, Schmidt, and Keyes (2002) in which changes in standard deviation units associated with positive practices were examined. This was done to examine the relative impact of changes in positive practices on effectiveness. Changes in positive practice scores between 2005 and 2007 were used to predict changes in measures of performance, comparing units that improved the most (top quartile) with units that improved least (bottom quartile). The differences in standard deviation units are summarized in Table 6 for positive practices as a whole ${ }^{(7)}$.

Table 6 about here

These results reveal that, with the exception of the overall satisfaction measure (which deteriorated in the health system between 2005 and 2007), units that improved the most in positive practices realized 0.7 standard deviation units greater improvement in patient satisfaction with pain management and in willingness to recommend the organization than did units that improved the least. This represents an approximately 26 percent increase in patient satisfaction rating in the units that improved the most. The highest improving units realized 0.2 standard deviation units better record regarding voluntary turnover than did the bottom quartile of nursing units (an 8 percent improvement). 
In measures relating to organizational climate and nurses' daily work, the effects of positive practices were even greater. Units that improved in positive practices between 2005 and 2007 achieved 1.1 standard deviation units higher scores in overall climate, 1.2 standard deviation units higher scores in participation in hospital affairs, 0.8 standard deviation units higher scores in foundations for quality care, 1.2 standard deviation units higher scores in support of nurses by managers, 1.0 standard deviation units higher scores in resource adequacy, and 0.3 standard deviation units higher scores in nurse/physician relations. These changes represent a 35 percent improvement or more for the top quartile units over the bottom quartile units. Improving overall positive practice scores appears to enhance various indicators of organizational effectiveness in nursing units.

\section{Strongest Positive Practices Predictors}

These findings made possible an examination of the second research question, "Which of the positive practices are most predictive of effectiveness?" Each performance criterion was examined individually, and the most predictive positive practices were identified using a cut-off level of 0.7 standard deviation units, representing at least a 25 percent or greater improvement in performance for improving organizations compared to non-improving organizations. Change scores between 2005 and 2007 were used so that a causal direction could be examined.

Table 7 reports the relationships between changes in positive practices and changes in organizational effectiveness for the top quartile improvers compared to the bottom quartile improvers. Table 8 summarizes these findings relative to the individual positive practice dimensions.

Table 7 about here

Table 8 about here 
Caring appears to be the only positive practices that accounted for little improvement in organizational effectiveness indicators in these nursing units. This is likely explained by the fact that at the very heart of a nursing unit is the core value and practice of caring. An intervention to increase positive practices is unlikely to dramatically affect that already-existing practice.

The central theme in the most predictive positive practices centers on the contributions made by the organization to the welfare of its human capital. That is, improvement in patient satisfaction, internal climate, employee participation, and quality of care occurs when organizations provide compassionate support for employees, emphasize positive and inspiring messages to employees, forgive mistakes, express gratitude to and confidence in employees, clarify the meaningfulness of the work being done, and reinforce an environment characterized by respect and integrity. No one positive practice stands out as the single most important determinant of improvement, but positive practices in combination appear to have the most powerful impact.

\section{Discussion}

The credibility of Positive Organizational Scholarship is dependent to some degree on its ability to demonstrate desired effects of organizational positivity on organizational performance and improvement. Unless bottom line outcomes are benefited, it is unlikely the organizations will invest resources in implementing positive practices. Moreover, in light of the criticisms of a positive orientation in the literature (George, 2004; Fineman, 2006; Hackman, 2008), its legitimate role in organizational science depends on empirical evidence. This study provides evidence that positive practices do, in fact, have a significant effect on organization-level effectiveness and improvement when indicators of effectiveness are selected by the organizations themselves.

In Study 1, positive practices in financial service business units were significantly associated with financial performance, work climate, turnover, and senior executive evaluations 
of effectiveness. In an industry in which positive practices might be assumed to carry little importance, organizational performance was substantially affected by the implementation of positive practices. In Study 2, improvement in positive practices over a two year period in health care units predicted improvements in turnover, patient satisfaction, organizational climate, employee participation in the organization, quality of care, managerial support, and resource adequacy. The specific positive practices that emerged as most predictive (in Study 2) were those associated with the development and support of human capital-including fostering respect, integrity, gratitude, compassion, forgiveness, inspiration, and meaningful work.

\section{Explanations for Positive Effects}

Figure 4 illustrates at least three sources of explanation for why positive practices elevate organizational performance-amplifying effects, buffering effects, and heliotropic effects. Whereas these explanatory mechanisms are not tested directly in this study, each is grounded in existing literature which provides a rationale for their explanatory role in linking positive practices to organizational performance. Several authors argue that a biological foundation exists for these factors linking positivity to outcomes (Lawrence \& Norhia,2002; Kok \& Fredrickson, 2010).

Figure 4 about here

Amplifying effects. Positive practices provide an amplifying effect because of their association with positive emotions and with social capital (Cameron, Bright, \& Caza, 2004). Several authors have reported that exposure to positive practices produces positive emotions in individuals, which, in turn, lead to elevation in individual performance in organizations (Fredrickson, 1998; Seligman, 2002; Fineman 1996; Staw, Sutton, \& Pellod, 1994; Tutu, 1999). (This is the first link in Figure 1.) When organization members observe compassion, experience gratitude, or witness forgiveness, for example, a mutually reinforcing cycle begins. Fredrickson 
(2003:173) reported that “. . elevation increases the likelihood that a witness to good deeds will soon become the doer of good deeds, then elevation sets up the possibility for some sort of upward spiral . . . and organizations are transformed into more compassionate and harmonious places." This effect is also well documented in the social networks literature (Christakis and Fowler, 2009). Staw \& Barsade (1993) found that positive emotions produce improved cognitive functioning, better decision making, and more effective interpersonal relationships among organization members. (This is the second link in Figure 1.) Employees experiencing positive emotions are more helpful to customers, more creative, and more attentive and respectful to one another (George 1998; Sharot, Riccardi, Raio, and Phelps, 2007).

A second rationale for the amplifying effects of positive practices is their association with social capital formation (Coleman, 1988; Baker, 2000). Social capital in organizations refers to the relationships among individuals through which information, influence, and resources flow (Adler \& Kwon, 2002; Leana \& Van Buren, 1999; Nahapiet \& Ghoshal, 1998). Several researchers have reported that when employees observe displays of positive practices among fellow employees—-for example, sharing, loyalty, advocacy, caring —-the results are enhanced liking, commitment, participation, trust, and collaboration, all of which may contribute to organizational performance (Podsakoff, MacKensie, Paine, \& Bachrach, 2000; Koys, 2001; Walz \& Niehoff, 2000). These enhanced relationships serve as the social capital upon which organizational performance is built. They form a reserve of resources that facilitates effectiveness. Gittell, Cameron, Lim, and Rivas (2006) identified this reserve of social relationships, for example, as the key predictor of airline company recovery after the 9-11 attacks. Organizational effectiveness is likely to be enhanced, therefore, because amplifying positive practices fosters a better organizational climate, better coordination and decision making, and better care of customers and fellow employees.

Buffering Effects. Positive practices also buffer the organization from the negative effects of trauma or distress by enhancing resiliency, solidarity, and a sense of efficacy (Masten 
\& Hubbard, Gest, Tellegen, Garmezy, \& Ramirez, 1999; Weick, Sutcliffe, \& Obstfeld, 1999). Seligman \& Csikszentmihalyi (2000) pointed out that the development of positive practices serves as a buffer against dysfunction and illness at the individual and group levels of analysis. They reported that compassion, courage, forgiveness, integrity, and optimism, for example, prevent psychological distress, addiction, and dysfunctional behavior (Seligman, Schulman, DeRubeis, \& Hollon, 1999).

At the group and organization levels, positive practices enhance the ability to absorb threat and trauma and to bounce back from adversity (Dutton, Frost, Worline, Lilius, \& Kanov, 2002; Wildavsky, 1991), including absorbing work related stress (Cohen, 2003; Kaplan, 2003; Kiecolt-Glaser, 2003), and healing from traumatic events (Powley \& Cameron, 2007). Positive practices serve as a source of resilience and "toughness" (Dienstbier \& Zillig, 2002), in other words, in helping to preserve social capital and collective efficacy (Sutcliffe \& Vogus, 2003), and in strengthening, replenishing, and limbering organizations (Worline, et al., 2003). They serve as buffering agents that protect and inoculate organizations, permitting them to bounce back from misfortune and to avoid deteriorating performance.

Heliotropic Effects. Positive practices also possess attributes consistent with heliotropism (Drexelius, 1627, 1862). The heliotropic effect is the attraction of all living systems toward positive energy and away from negative energy, or toward that which is life-giving and away from that which is life-depleting (Smith \& Baker, 1960; D'Amato \& Jagoda, 1962; Mrosovsky \& Kingsmill, 1985). Organizations characterized by positive practices foster positive energy among members, and positive energy produces elevated performance (Erhardt-Siebold, 1937; Dutton, 2003; Cameron, 2008b).

Several explanations have been proposed for why heliotropic tendencies exist in human beings and their systems. Erdelyi (1974) explained positive biases as a product of individual cognitive development. Perceptual defense mechanisms (e.g., denial, displacement) emerge to counteract the effects of negative information, so inclinations toward positivity develop in the 
brain. In brain scan research, Sharot, Riccardi, Raio, and Phelps (2007:102) found that the human brain tends toward optimistic and positive orientations in its natural state, and that more areas of the brain activate when positive and optimistic images are processed compared to negative or pessimistic images. Unkelbach, et al. (2008) reported a series of studies showing that the human brain processes positive information faster and more accurately than negative information, so human productivity and performance are elevated by the positive more than the negative. Learning theorists (e.g., Skinner, 1965) explain positive biases as being associated with reinforcement. Activities that are positively reinforcing are repeated while activities that are punishing or unpleasant are extinguished.

Organizationally, heliotropic tendencies in social processes can be explained by the basic motivation in social systems to organize (Merton, 1968; Weick, 1999). Simply stated, organizing occurs in order to benefit the collective, so that human organizations, at their core, are intended to facilitate positive benefits. The eudemonic tendency in human beings leads people toward helping or contributing behaviors (Krebs, 1987), and when others observe these behaviors they feel compelled to join with and build upon those contributions (Sethi and Nicholson, 2001). Gouldner (1960) proposed that role modeling and social norm formation create a tendency toward the positive. Positive social processes are more likely to survive and flourish over the long run than negative social processes because they are functional for the group. Collectivities survive when they rely on positive norms, and these norms are a direct product of demonstrated positive practices. Evolutionarily, the dysfunctional effects of nonpositive practices eventually cause them to become extinguished.

The point is that at least three explanations find grounding in the literature for why positive practices are predictive of organizational effectiveness. Cognitively, emotionally, behaviorally, physiologically, and socially, evidence suggests that human systems naturally prefer exposure to the positive, so it is expected that organizational performance would be enhanced by positive practices. 


\section{The Role of the Negative}

It is important to keep in mind, of course, that some of the greatest triumphs, most noble virtues, and highest achievements result from the presence of negative occurrences. In fact, common human experience as well as abundant scientific evidence supports the idea that negativity has an important place in producing positive outcomes. A comprehensive review of psychological research by Baumeister, Bratslavsky, Finkenauer, \& Vohs (2001) articulated this conclusion in the article's title: "Bad is stronger than good." Human beings, they pointed out, react more strongly to negative phenomena than to positive phenomena, or to stimuli that threaten their existence or that signal maladaptation. Negative events have a greater impact than positive events of the same type (e.g., losing friends or money has a larger impact than winning friends or money; it takes longer for negative emotions to dissipate; less information is needed to confirm a negative trait in others; people spend more thought time on negative relationships than positive ones). Therefore, the positive can overcome the powerful effects of the negative only by superior force of numbers.

In three controlled experiments, however, Wang, Galinski, and Murnighan (2009) found that the negative has its strongest effects on emotions and psychological reactions, whereas the positive has its strongest effects on behavior. They concluded that "bad affects evaluations more than good does, but that good affects behavior more than bad does" (p. 642).

The point is, tendencies toward protection and survival make negative events and negative stimuli extremely potent in affecting human emotions and, potentially, organizational performance (Maslow, 1968; Alderfer, 1966). Because bad tends to be stronger than good (Baumeister, et al., 2001), extra emphasis on positive practices is usually required for positive effects to accrue in organizations, but most organizations remain focused on negative phenomena. This helps to explain why so little research is conducted on positive phenomena in organizational studies. A larger effect $\left(R^{2}\right)$ is usually detected by accounting for negative 
phenomena compared to positive phenomena-that is, the bad has stronger effects than the good (Baumeister, et al., 2001)—so it is understandable that most research focuses on the factors accounting for the most variance. Because negative effects usually dominate heliotropic inclinations, and they usually account for a larger amount of variance in behavior change, they traditionally capture more attention in scholarly analyses (Seligman, 1999). This is one reason why such a dearth of research has focused on the relationships between positively deviant, affirmative, and virtuous practices and organizational performance.

\section{Conclusion}

Figure 1 summarizes the assumed relationships appearing in past literature between positive practices in the workplace, positive affect, positive individual behavior, and organizational effectiveness. The link with organizational effectiveness, unfortunately, is in need of empirical confirmation. It has been established empirically that positive practices produce positive affect in individuals (the first link in Figure 1)—such as satisfaction with work, personal well-being, intention to quit (reversed), conflict (reversed), and social satisfaction (Lyubomirsky, King, \& Diener, 2005; Donovan, 2000; Foster, et al., 2004; Van Katwyk, et al., 2002; Cooper, et al., 1992). Bono and Ilies (2006) found, for example, that leaders who fostered positive emotions also generated more commitment and satisfaction among others.

It has also been established that positive emotions affect individual performance at work (the second link in Figure 1) such as job performance, engaging in occupational activities, providing support, organizational citizenship behaviors, work withdrawal (reversed), counterproductive work behavior (reversed), and social interactions with others (Crede et al., 2005; Donovan, et al., 2000; George, 1995; Jundt \& Hinsz, 2001; Mishra, 1992; Baldassare, et al., 1984; Philips, 1967; Harter, Schmidt, \& Keyes, 2002). For example, Giacalone, et al. (2005) found that individuals who experienced the emotions of gratitude and hope were more concerned about corporate social responsibility. Luthans and colleagues (2007) found that 
psychological capital (resilience, hope, optimism, and self-efficacy) produced satisfaction, motivation, commitment, and intention to stay. The unaddressed question has been, however, does organizational performance improve as a result (the third link in Figure 1)?

The studies reported in these two investigations uncover evidence that organizational performance is, in fact, affected by the implementation of positive practices at the organization level of analysis, even though the available outcomes data were less than ideal. Explanations for why positive practices improve organizational effectiveness rely on three factors-the amplifying effects of positive practices, the buffering effects of positive practices, and the heliotropic effects unleashed by positive practices. Positivity becomes self-reinforcing (amplifying), it fosters resiliency against negative and challenging obstacles (buffering), and it possesses attributes consistent with heliotropism (Cooperrider \& Srivastva, 1987) -the inherent tendency toward positive energy and away from negative energy (e.g., Smith \& Baker, 1960; D’Amato \& Jagoda, 1962; Mrosovsky \& Kingsmill, 1985). Fredrickson's (2001) "broaden and build theory" has confirmed that, on the individual level, thought-action repertoires are expanded and broadened, and resources and capabilities are elevated and enlarged (built) in the presence of positivity. The results reported here suggest a similar dynamic in organizations.

\section{Limitations}

The results of these two investigations, of course, are suggestive and not conclusive. Several limitations of the studies constrain the confidence with which conclusions can be drawn and implications identified. For example, in both studies the organizational sample sizes were small, and variance in outcome variables, in particular, was quite significantly constrained. In financial services, the coded form of the financial data, the availability of only six units with financial outcomes, one item measures on the independent climate survey, and the fact that the business units were all within a single large firm constrained the extent to which statistically significant results could be detected. In the health care organizations, the unavailability of 
relevant data for all units and the lack of outcomes data on units that did not receive exposure to POS also constrained the opportunity to uncover significance. All the organizations in these studies had engaged in conscious efforts to learn about and implement positive practices, so differences between these organizations and a control group not exposed to positive practices would most likely have highlighted even larger and more comprehensive differences. Constrained variance is an important limitation.

In addition, relying on a survey instrument to assess positive practices in both studiesrather than conducting, for example, a quasi-experimental design including direct observation of implementation with longitudinal data—also constrains the extent to which unequivocal relationships can be specified. Not being able to identify differential impact among positive practices on performance, for example, may have been a product of common method bias (e.g., a single survey instrument measuring the different practices), rather than an actual absence of differential effects. Common method bias is always a concern when relying upon survey instruments. Furthermore, rich descriptions of how and why certain units were more successful than others in implementing positive practices over time are also unavailable because of this study design.

\section{Future Research Directions}

Because the amount and scope of research on the relationship between positive practices and organizational effectiveness has been limited to date, a variety of issues are in need of attention, including (1) the measurement of positive practices, (2) the predictive power of positive practices, and (3) the moderators and mediators of positive practices on performance outcomes.

Measurement. Which positive practices are key in accounting for organizational performance has yet to be precisely established. Other positive practices in addition to those considered in this paper are likely to be important. In addition, theories of positive practices 
have not yet been fully developed, and the conceptual boundaries and nomological network associated with those concepts is in need of specification. Survey instruments that assess positive practices might be referred to as "blunt" instruments in that they provide aggregated ratings of positive practices in organizations, but experimental manipulations and carefully designed organizational interventions are needed to help clarify how positive practices are implemented and what effects they have over time. Investigating which practices are most important in creating high levels of effectiveness is an important challenge for future researchers.

Prediction. Thus far, no single positive practice appears to account for any more variance in outcomes than others. This may be a product of imprecise measurement, or it may be a product of positive practices not being displayed in isolation from one another. If the latter is true, then investigations of which clusters of positive practices occur naturally together in organizations would be most useful. Moreover, identifying which positive practice clusters are most closely associated with which outcomes is also an important area for study. Are the same positive practices, for example, predictive of financial performance as of employee engagement or of customer satisfaction? It is also not clear which specific interventions are most helpful in raising positive practice scores. Determining explicitly how to assist organizations in implementing positive practices is an area of needed investigation. Moreover, consistent with Gladwell's (2002) concept of "tipping point," it is important to understand how much positivity is enough. Is there a ratio-such as the now-famous $3: 1$ ratio of positive to negative emotions which predicts flourishing outcomes (Fredrickson, 2009)—which also predicts organizational outcomes? How much is enough?

Moderators and Mediators. Another set of issues has to do with the extent to which positive practices have direct or moderated effects on desired outcomes. What moderators exist in determining how these practices act upon the organization to produce performance outcomes? Research has been cited in this paper suggesting that amplifying, buffering, and heliotropic tendencies are inherently associated with positive practices, and Cameron (2003) 
summarized literature suggesting that positive practices enhance social capital which reduces transaction costs, facilitates communication and cooperation, enhances employee commitment, fosters individual learning, and strengthens relationships and involvement. Positive practices also foster prosocial behavior which, ostensibly, would likely lead to higher performance. Investigating which factors, if any, serve as moderators between positive practices and performance will certainly be a fruit area for future investigations. To date, almost no attention has been paid to what these factors might be. For example, demographic differences such as the size of an organization, its culture, the demographic make-up of the top management team, the explicit goals and strategy of the organization, certain industry dynamics, and so forth, may be important mediators of the relationships between virtuousness and performance. Limited examination of moderators and mediators has occurred to date.

In sum, a propensity to focus on problems, challenges, and competitive contests exists in organizational science (Margolis \& Walsh, 2003). Positive Organizational Scholarship advocates the examination of positive dynamics that may account for previously untapped variance in performance. The two studies reported here represent one step in uncovering evidence that when positive practices are given added emphasis, human systems tend toward positive change. High levels of effectiveness in organizations have been documented when the positive dominates the negative.

\section{Notes}

(1) Each of the nominated positive practices had received some support regarding its potential relationship with various aspects of organizational performance. For example, Cameron, Bright, and Caza (2004) found significant relationships between forgiveness, compassion, integrity, trust, and optimism and organizational climate and financial performance. 
Dutton and colleagues (2006) found associations between mutuality, cohesion, strong ties, openness, friendship, and positive communication and some indicators of organizational performance. Baker and colleagues (2003) found similar support for shared energy, fluid expertise, and unit influence. Wrzesniewski (2003) identified the positive effects of transcending self-interest, meaning, and renewal on organizational members. Grant and colleagues (2007) found that positive emotions, caring and giving behavior, and prosocial identity fostered commitment to the organization. Gratitude, hope, empathy, and love were found to significantly predict commitment, satisfaction, motivation, and turnover (Andersson, et al., 2007; Giacalone, et al., 2005; Fry, et al., 2005; Kellett, et al., 2006; Gittell, et al., 2006; Luthans, et al., 2007).

(2) This survey was also administered in several other organizations and industries (e.g., county governments, manufacturing, pharmaceutical, telecom, IT firms) in order to examine the factor structure $(\mathrm{N}=5400)$. The factor structure used in this study also emerged as stable in each of these other survey administrations.

(3) These six dimensions, as it turns out, are very similar to a proposed comprehensive list of virtues reported in prior published literature. Specifically, in one of the few published listings of proposed virtuous practices in organizations, Chun (2005) reviewed several previous inventories of virtues, then analyzed the corporate ethical value statements of 158 Fortune Global firms. Her analyses produced six dimensions of virtuous practices. These six dimensions incorporated lists of individual virtues proposed by Aristotle, Solomon (1999), Murphy (1999), Moberg (1999), and Shanahan \& Hyman (2003). Each of Chun's six dimensions is incorporated within the 6 positive practice dimensions that emerged in this study. Specifically, Chun's "integrity" is assessed as "respect, integrity, and gratitude" in this study. Chun's "empathy" is assessed as "compassionate support" in this study. Chun's "warmth" is assessed as "caring" in this study. Chun's "courage" has similar items as "meaning" in this study. 
Chun's "conscientiousness" has similar items as "forgiveness" in this study. And Chun's "zeal" is assessed at "inspiration" in this study. This parenthetical finding helps support the validity of these six positive practices.

(4) Among the positive practices initiatives implemented in both the financial services and the health care units were two different multi-day senior leadership workshops—-the first with the CEO and the direct reports, and the second with a larger group of the top leaders in the organization-in which POS was explained. Evidence for the connection to employee wellbeing and organizational performance was explained. Half-day follow-up meetings were also conducted with various groups of people (e.g., the sales force, the RNs, and so forth) to expose larger groups of employees to the rationale and evidence for POS. This was also an opportunity to explain some of the positive practices that leaders planned to implement. A positive energy network map (Baker, 2000) was constructed in the organizations, and the employees occupying the "nodes" of that positive energy map were designated as a "change team." This team of positive energizers was assigned to help disseminate the message and assist in implementing the practices related to POS throughout the organizations. Separate training sessions were held with the change team, and the team met together weekly to coordinate efforts. Each of the top leaders, as well as the members of several units, participated in a "reflected best-self feedback" process in which they received approximately 60 behavioral descriptions of their best-selves, or their highest value contributions, from which behavioral action plans were constructed consistent with positive practices. A Personal Management Interview program was instituted in many of the units (see Cameron, 2008b) in which monthly one-on-one meetings were institutionalized, again, to reinforce positive practices and organizational improvement. Many units established "Everest goals" which redirected energy and focus from monetary, market share, or medical error targets to outcomes representing positively deviant, profoundly meaningful, and inherently energizing outcomes. 
(Everest goals, in addition to being SMART, are characterized by: positive deviance, "goods of first intent," an affirmative bias, a significant contribution, and sustainable positive energy.) Employee engagement strategies were implemented in which investments in financial capital, social capital, and intellectual capital were supplemented by investments in ideological capital which centered on practices consistent with the Positive Practices Survey. Each unit also spent at least one day with an external facilitator identifying how these positive practices would be implemented in their own organization and what kinds of accountability mechanisms would be put in place. This facilitator served as a process consultant to assist units in crafting their own positive change agenda. More explanation of these various interventions and practices is available in Cameron (2008b) and in Vannette \& Cameron (2008).

(5) Neither correlation coefficient reaches statistical significance at the $p>.05$ level. Due to the small degrees of freedom, the correlation would need to be approximate .80 to reach significance.

(6) Indictors of effectiveness were reasonably similar in the two studies but not exactly the same. Voluntary employee turnover was captured in both studies. Organizational climate ratings from outside consulting firms were captured in both studies. Patient satisfaction ratings in the health care units have a parallel with financial performance in the financial services units. Willingness to recommend the hospital in health care units have a parallel with expert ratings in financial services.

(7) These analyses simply show the amount of change, expressed in standard deviation units, that occurs in the outcome variable based on the predictor variable. A standard deviation unit is computed by subtracting the mean of the top group from the mean of the bottom group and dividing by the overall standard deviation of the entire population. 


\section{Table 1: $\quad$ Positive Practices Dimensions with Definitions}

\section{Caring}

People care for, are interested in, and maintain responsibility for one another as friends.

\section{Compassionate Support}

People provide support for one another including kindness and compassion when others are struggling.

\section{Forgiveness}

People avoid blame and forgive mistakes.

\section{Inspiration}

People inspire one another at work.

\section{Meaning}

The meaningfulness of the work is emphasized, and people are elevated and renewed by the work.

\section{Respect, Integrity, and Gratitude}

People treat one another with respect and express appreciation for one another. They trust one another and maintain integrity. 
Table 2

Means, Standard Deviations, Correlations, and Factor Loadings

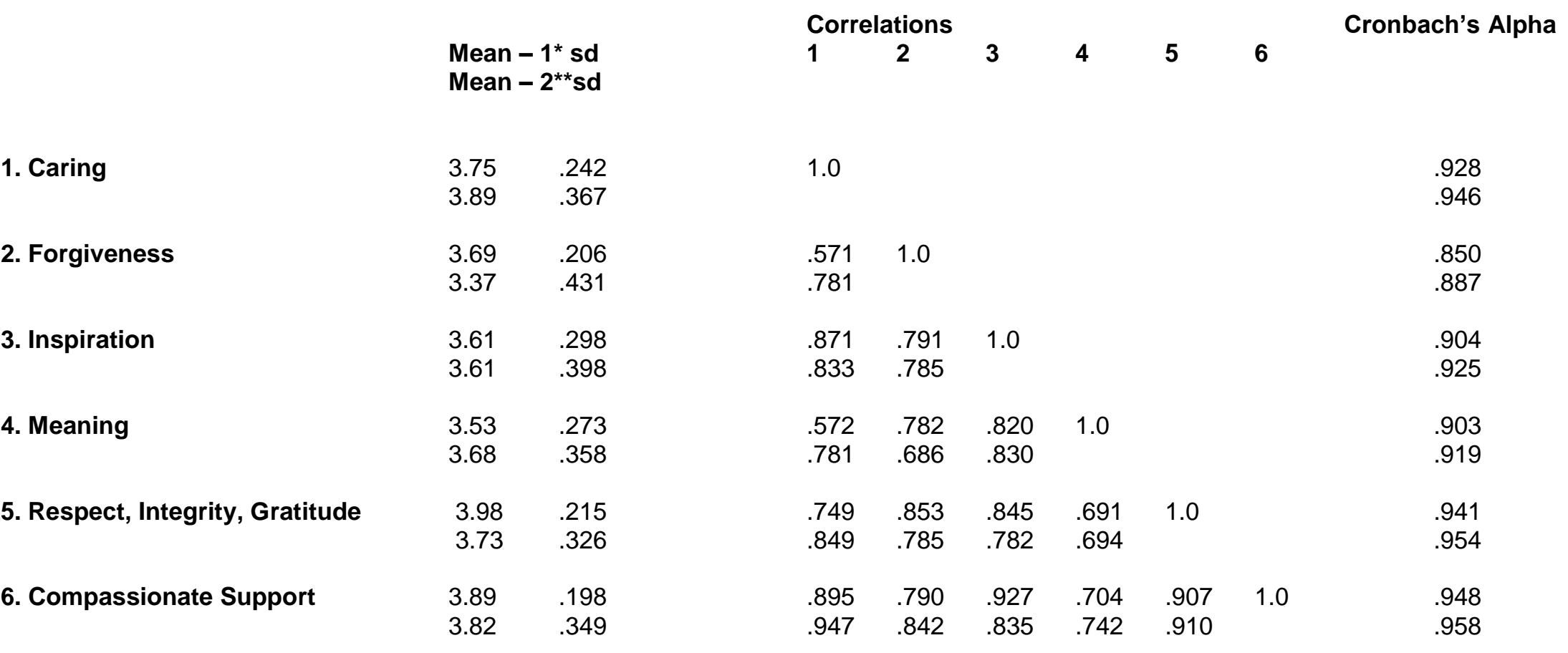

* $\quad 1=$ refers to study 1 in the financial services industry; 2 = refers to the 2005 data from the health care industry study, before any interventions occurred and before outcomes data were assessed. The top line is always study 1 ; the bottom line is always study 2 .

** To conserve space, only the 2007 health care descriptive statistics are provided, rather than both 2005 and 2007. 
Table 3: $\quad$ Correlations Between Positive Practices, Financial Performance, and Senior Executives' Ratings of Two Measures of Effectiveness

\section{Ranking of Senior Executives Regarding \\ Effectiveness Engagement}

$\begin{array}{lll}\text { Positive Practices } & .7714 & .7333 \\ \text { Financial Performance } & .6381 & .5809\end{array}$

Table 4: $\quad$ Top Quartile Organizations in Overall Positive Practices Compared to Bottom Quartile Organizations on Effectiveness Indicators, 2007 data.

\begin{tabular}{|l|c|c|c|}
\hline \multicolumn{1}{|c|}{ Indicator of Effectiveness } & $\begin{array}{c}\text { Units Scoring the } \\
\text { Highest }\end{array}$ & $\begin{array}{c}\text { Units Scoring } \\
\text { the Lowest }\end{array}$ & $\begin{array}{c}\text { Mann-Whitney } \\
\text { U-Test }\end{array}$ \\
\hline & & & \\
\hline Overall Satisfaction & 88.0 & 86.1 & 0.06 \\
\hline Patient Satisfaction - Pain Mgmt. & 88.1 & 85.9 & 0.17 \\
\hline Willingness to Recommend & 81.8 & 66.0 & 0.29 \\
\hline Turnover & 10.2 & 10.4 & 0.77 \\
\hline Organizational Climate & 3.0 & 2.7 & 0.02 \\
\hline Participation in Hospital Affairs & 3.0 & 2.7 & 0.24 \\
\hline Foundations for Quality Care & 3.1 & 2.9 & 0.25 \\
\hline Manager Support of Nurses & 3.1 & 2.7 & 0.04 \\
\hline Resource Adequacy & 2.9 & 2.6 & 0.08 \\
\hline Nurse/Physician Relations & 2.9 & 2.0 & 0.04 \\
\hline
\end{tabular}


Table 5: $\quad$ Top Quartile Organizations Compared to Bottom Quartile Organizations in Improvement of Positive Practices Between 2005 and 2007 - Overall Change Scores

\begin{tabular}{|l|c|c|c|}
\hline \multicolumn{1}{|c|}{ Indicator of Effectiveness } & $\begin{array}{c}\text { Units That } \\
\text { Improved the Most }\end{array}$ & $\begin{array}{c}\text { Units That Did Not } \\
\text { Improve }\end{array}$ & $\begin{array}{c}\text { Mann-Whitney } \\
\text { U-Test }\end{array}$ \\
\hline & & & \\
\hline Overall Satisfaction & 1.80 & 1.17 & 0.51 \\
\hline Patient Satisfaction - Pain Mgmt. & 1.30 & 1.00 & 0.51 \\
\hline Willingness to Recommend & -1.10 & -8.00 & 0.32 \\
\hline Turnover & 1.75 & 2.58 & 0.77 \\
\hline Organizational Climate & 0.20 & -0.05 & 0.08 \\
\hline Participation in Hospital Affairs & 0.19 & 0.03 & 0.25 \\
\hline Foundations for Quality Care & 0.06 & 0.07 & 0.56 \\
\hline Manager Support of Nurses & 0.31 & -0.24 & 0.08 \\
\hline Resource Adequacy & 0.17 & -0.15 & 0.08 \\
\hline Nurse/Physician Relations & 0.21 & -0.10 & 0.04 \\
\hline
\end{tabular}

Table 6: $\quad$ Changes in Standard Deviation Units When Comparing Organizations that Improved the Most in Positive Practices with Those that Improved the Least Overall Positive Practice Scores

\begin{tabular}{|c|c|c|c|}
\hline $\begin{array}{c}\text { 2005-2007 Change } \\
\text { in Organizational } \\
\text { Effectiveness }\end{array}$ & $\begin{array}{c}\text { Bottom Quartile } \\
\text { Mean }\end{array}$ & $\begin{array}{c}\text { Top Quartile } \\
\text { Mean }\end{array}$ & $\begin{array}{c}\text { Difference in } \\
\text { Standard } \\
\text { Deviation Units }\end{array}$ \\
\hline $\begin{array}{c}\text { Overall Patient } \\
\text { Satisfaction }\end{array}$ & .620 & -.100 & -0.4 \\
\hline $\begin{array}{c}\text { Patient Satisfaction - } \\
\text { Pain Management }\end{array}$ & -1.120 & .550 & 0.7 \\
\hline $\begin{array}{c}\text { Patient Satisfaction } \\
\text { Willingness to } \\
\text { Recommend }\end{array}$ & -6.033 & -1.600 & 0.7 \\
\hline Turnover & -1.431 & -.595 & 1.1 \\
\hline Overall Climate & -.059 & .171 & 1.2 \\
\hline $\begin{array}{c}\text { Participation in } \\
\text { Hospital Affairs }\end{array}$ & -.069 & .187 & 0.8 \\
\hline $\begin{array}{c}\text { Foundations for } \\
\text { Quality Care }\end{array}$ & -.047 & .061 & 1.2 \\
\hline $\begin{array}{c}\text { Manager Support of } \\
\text { Nurses }\end{array}$ & -0.64 & .414 & 1.0 \\
\hline Resource Adequacy & -.177 & .086 & 0.3 \\
\hline $\begin{array}{c}\text { Nurse/Physician } \\
\text { Relations }\end{array}$ & .018 & .096 & 0.2 \\
\hline
\end{tabular}


Table 7: $\quad$ Predictors of Organizational Effectiveness Comparing Organizations that Improved the Most in Positive Practices with Those that Improved the Least - 2005-2007 - Using Standard Deviation Units

\begin{tabular}{|c|c|c|c|c|c|c|c|c|c|c|c|}
\hline & $\begin{array}{c}\text { Overall } \\
\text { Patient } \\
\text { Satisfaction } \\
\text { Score } \\
\end{array}$ & $\begin{array}{c}\text { Pain } \\
\text { Management }\end{array}$ & $\begin{array}{c}\text { Willingness } \\
\text { to } \\
\text { Recommend } \\
\text { to Others }\end{array}$ & Turnover & $\begin{array}{l}\text { Overall } \\
\text { Climate }\end{array}$ & $\begin{array}{c}\text { Participation } \\
\text { in Hospital } \\
\text { Affairs }\end{array}$ & $\begin{array}{l}\text { Foundations } \\
\text { for Quality } \\
\text { Care }\end{array}$ & $\begin{array}{c}\text { Manager } \\
\text { Support } \\
\text { of } \\
\text { Nurses }\end{array}$ & $\begin{array}{l}\text { Resource } \\
\text { Adequacy }\end{array}$ & $\begin{array}{l}\text { Nurse/Physician } \\
\text { Relations }\end{array}$ & $\begin{array}{l}\text { Row } \\
\text { Sum }\end{array}$ \\
\hline Caring & -1.3 & 0.0 & 1.0 & -0.1 & 0.5 & 0.5 & 0.1 & 0.8 & 0.2 & -0.3 & 1.4 \\
\hline $\begin{array}{r}\text { Compassionate } \\
\text { Support } \\
\end{array}$ & -0.3 & 0.8 & 0.9 & 0.0 & 0.7 & 0.8 & 0.4 & 0.9 & 0.6 & 0.0 & 4.8 \\
\hline Forgiveness & 0.0 & 1.7 & -0.8 & 0.0 & 1.2 & 1.6 & 1.2 & 1.0 & 1.0 & 0.5 & 7.4 \\
\hline Inspiration & 0.2 & 1.0 & 0.0 & 0.1 & 1.1 & 1.1 & 0.8 & 1.2 & 0.9 & 0.4 & 6.8 \\
\hline Meaning & -0.1 & 0.9 & -0.1 & 0.1 & 0.8 & 0.9 & 0.4 & 1.0 & 0.5 & -0.2 & 4.4 \\
\hline $\begin{array}{l}\text { Respect, } \\
\text { Integrity, } \\
\text { Gratitude }\end{array}$ & -0.4 & 0.4 & 1.9 & -0.3 & 1.0 & 1.0 & 0.5 & 1.2 & 0.7 & 0.1 & 6.1 \\
\hline Column Sum & -1.9 & 4.8 & 2.9 & -0.2 & 5.3 & 5.9 & 3.4 & 6.1 & 3.9 & 0.5 & 30.9 \\
\hline
\end{tabular}


Table 8: $\quad$ Positive Practices That Predict Indicators of Organizational Effectiveness

\begin{tabular}{|l|l|}
\hline Indicators of Effectiveness & Positive Practice Dimensions (<0.7 standard deviation units) \\
\hline Overall Patient Satisfaction & Caring (reversed) \\
\hline $\begin{array}{l}\text { Patient Satisfaction - Pain } \\
\text { Management }\end{array}$ & Compassionate Support; Forgiveness; Inspiration; Meaning \\
\hline $\begin{array}{l}\text { Patient Satisfaction - Willingness } \\
\text { to Recommend }\end{array}$ & Caring; Compassionate Support; Respect, Integrity, and Gratitude \\
\hline Turnover & None \\
\hline Overall Organizational Climate & $\begin{array}{l}\text { Compassionate Support; Forgiveness; Inspiration; Meaning; } \\
\text { Respect, Integrity, and Gratitude }\end{array}$ \\
\hline Participation in Hospital Affairs & $\begin{array}{l}\text { Compassionate Support; Forgiveness; Inspiration; Meaning; } \\
\text { Respect, Inspiration, and Gratitude }\end{array}$ \\
\hline Foundations for Quality Care & Forgiveness; Inspiration \\
\hline Manager Support of Nurses & $\begin{array}{l}\text { Caring; Compassionate Support; Forgiveness; Inspiration; Meaning; } \\
\text { Respect, Integrity, and Gratitude }\end{array}$ \\
\hline Resource Adequacy & Forgiveness; Inspiration; Respect, Integrity, and Gratitude \\
\hline Nurse/Physician Relations & None \\
\hline
\end{tabular}

\begin{tabular}{|c|c|c|}
\hline $\begin{array}{c}\text { Positive Practice } \\
\text { Dimensions }\end{array}$ & $\begin{array}{c}\text { Number of Strong Predictive } \\
\text { Relationships (<0.7 standard } \\
\text { deviation units) }\end{array}$ & $\begin{array}{c}\text { Sum Total of Standard } \\
\text { Deviation Units }\end{array}$ \\
\hline Caring & 2 & 1.4 \\
\hline Compassionate Support & 5 & 7.8 \\
\hline Forgiveness & 7 & 6.8 \\
\hline Inspiration & 6 & 4.4 \\
\hline Meaning & 4 & 6.1 \\
\hline $\begin{array}{c}\text { Respect, Integrity, } \\
\text { Gratitude }\end{array}$ & 5 & \\
\hline
\end{tabular}


Figure 1: The Assumed Connections Between Positive Practices and Organizational Effectiveness

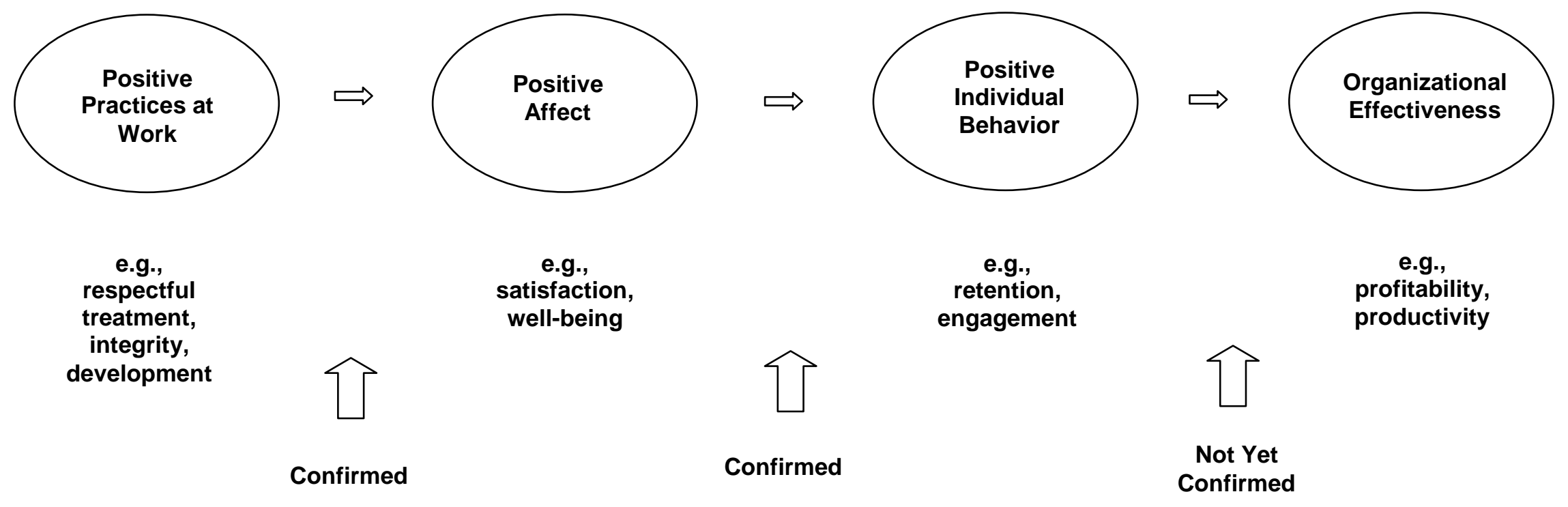


Figure 2: $\quad$ Relationships Between Positive Practices and Climate Factors (vertical axis = climate factor; horizontal axis = positive practices)

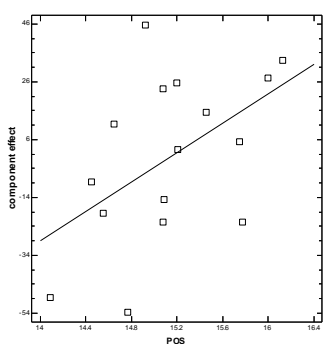

Work Climate

$\mathrm{T}=2.2$

$p<.05$

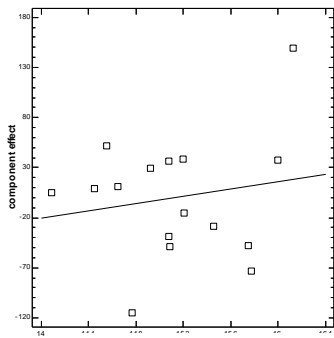

Connection to

Mission

$\mathrm{T}=.65$

$\mathrm{P}=$ n.s.

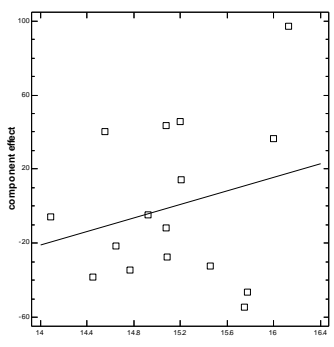

Personal

Influence

$\mathrm{T}=.96$

$\mathrm{P}=$ n.s.

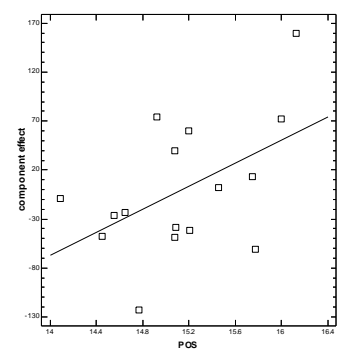

Managerial

Effectiveness

$\mathrm{T}=2.15$

$p<.05$

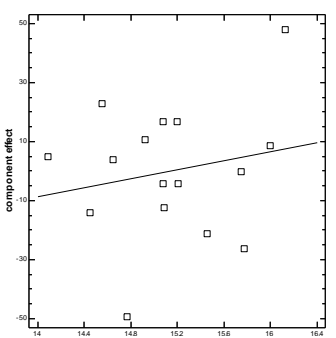

Employer of

Choice

$\mathrm{T}=.74$

$\mathrm{P}=$ n.s.

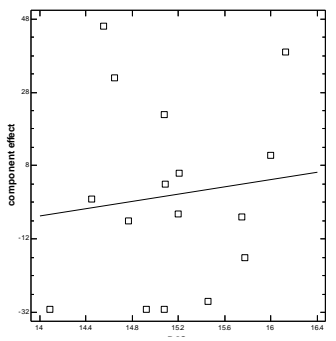

Work-Life

Balance

$\mathrm{T}=.49$

$\mathrm{P}=\mathrm{n} . \mathrm{s}$.

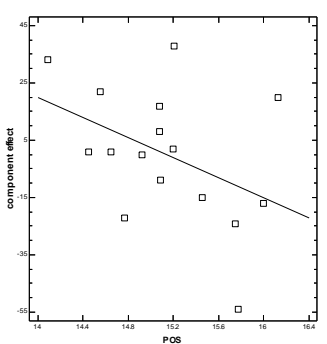

Employee Retention (intent to leave)

$T=-1.8$

$\mathrm{p}<.09$
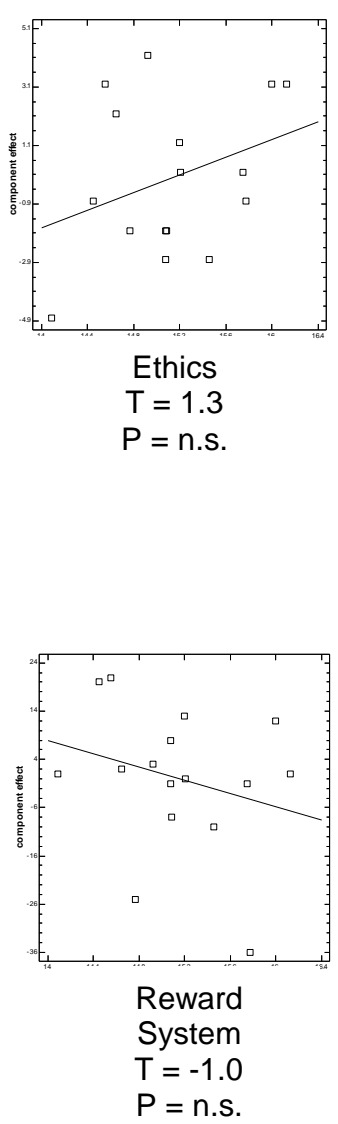
Figure 3: A Comparison of Units Included in the Study with Units Not Included in the Study but in the Same Health Care System - Improvement in Positive

Practices

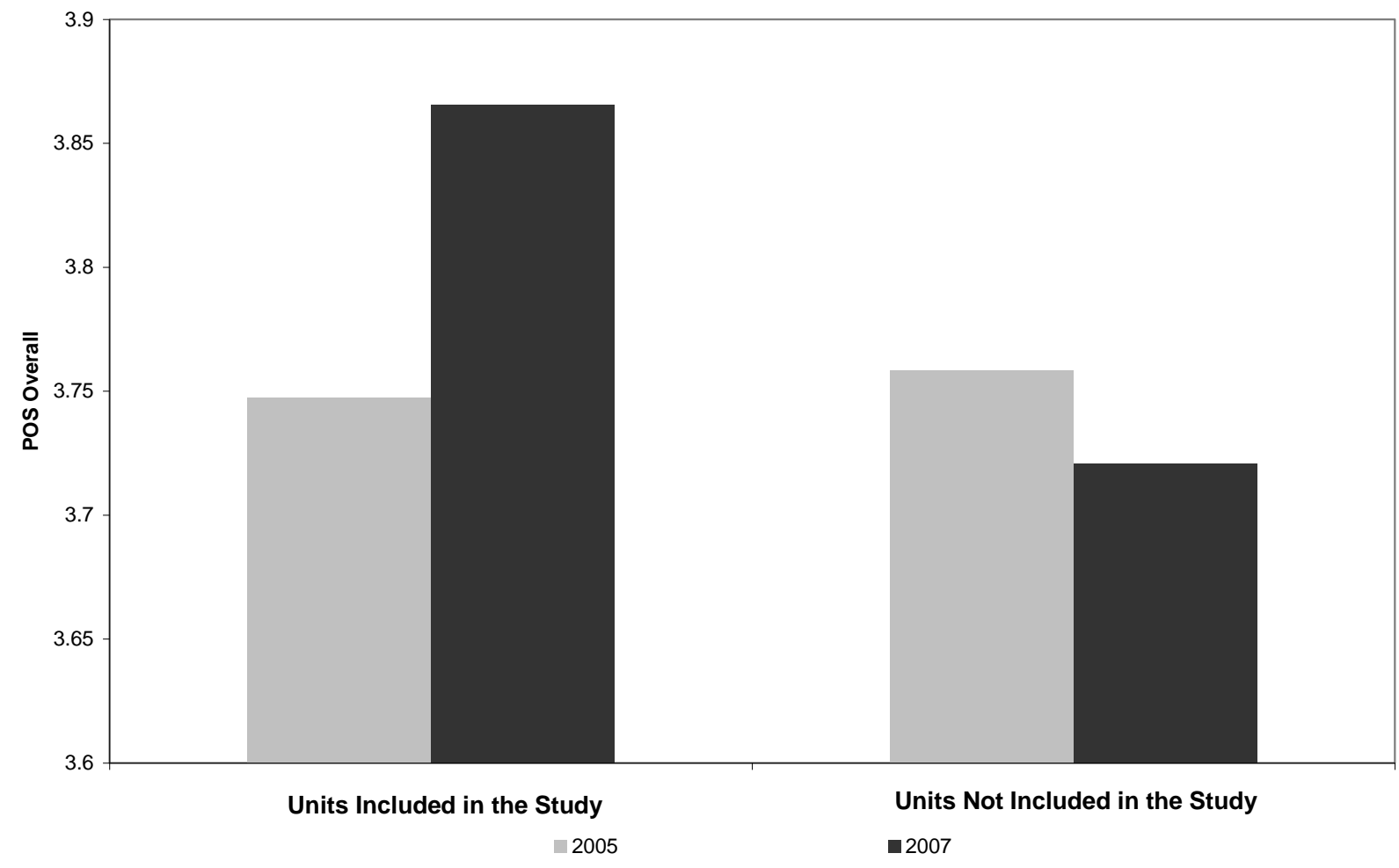


Figure 4: Explaining the Effects of Positive Practices on Organizational Effectiveness

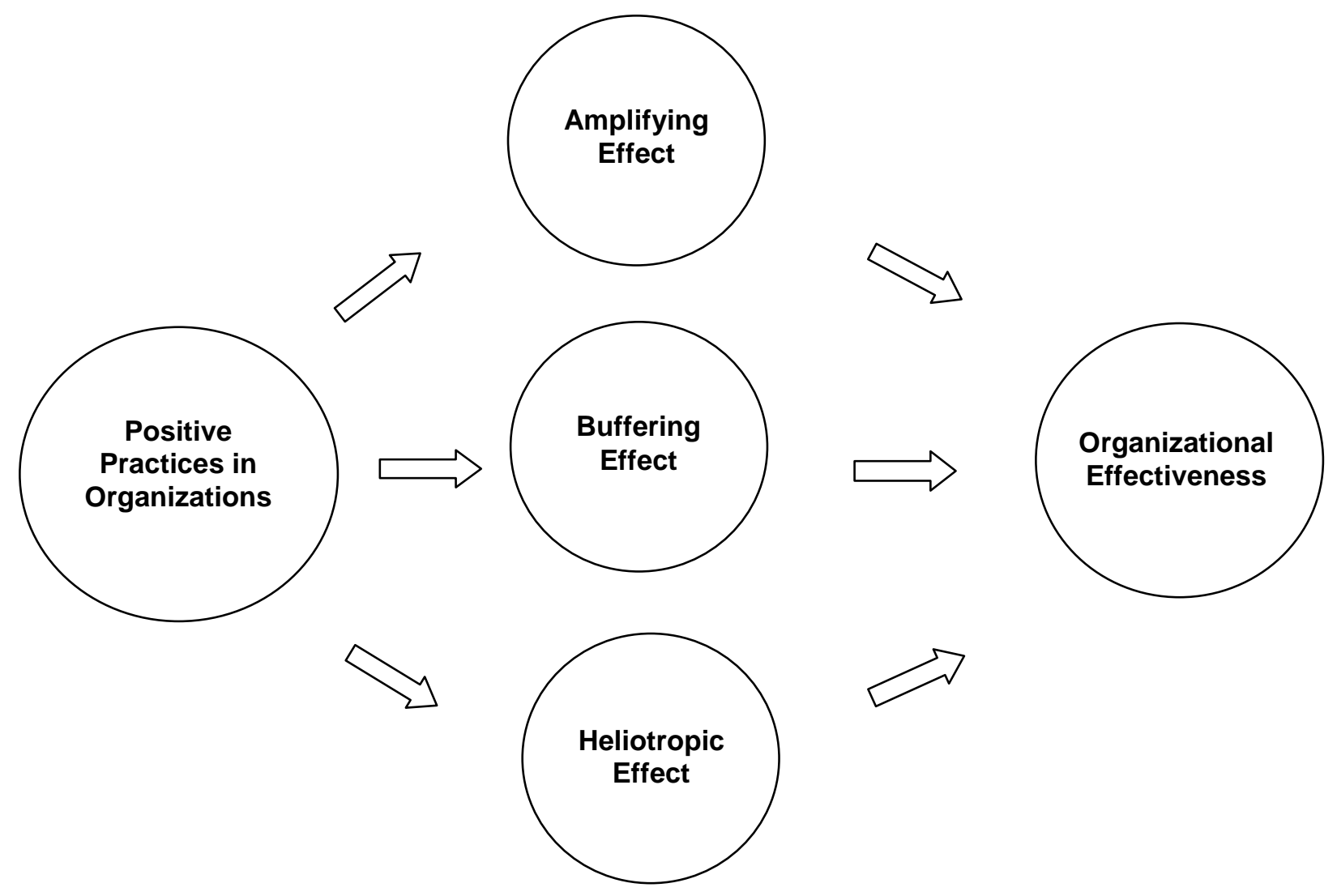


Appendix A: Rotated Components Matrix from Factor Analysis from Financial Services

\begin{tabular}{|c|c|c|c|c|c|c|}
\hline & $\begin{array}{c}\text { Dignity \& } \\
\text { Respect }\end{array}$ & Support & Caring & Meaning & Inspiration & Forgiveness \\
\hline \multicolumn{7}{|l|}{ Dignity \& Respect } \\
\hline $\begin{array}{l}\text { We treat each other with } \\
\text { respect }\end{array}$ & .685 & .054 & .039 & .018 & -.093 & -.030 \\
\hline We trust one another & .684 & .068 & .091 & .064 & -.043 & -.028 \\
\hline $\begin{array}{l}\text { We demonstrate } \\
\text { integrity }\end{array}$ & 641 & .027 & -.030 & .025 & -.029 & .059 \\
\hline $\begin{array}{l}\text { We foster dignity in } \\
\text { each other }\end{array}$ & .579 & .091 & -.018 & .007 & .037 & -.019 \\
\hline $\begin{array}{l}\text { We display confidence } \\
\text { in one another }\end{array}$ & .569 & .087 & -.043 & .126 & .102 & -.038 \\
\hline $\begin{array}{l}\text { We show appreciation } \\
\text { for one another }\end{array}$ & .463 & .117 & -.052 & .095 & -.004 & .009 \\
\hline $\begin{array}{l}\text { We express gratitude to } \\
\text { each other }\end{array}$ & 279 & .063 & -.022 & .052 & -.085 & .020 \\
\hline \multicolumn{7}{|l|}{ Support } \\
\hline $\begin{array}{l}\text { We help people who are } \\
\text { facing difficulty }\end{array}$ & -.009 & .797 & -.009 & .054 & .012 & -.019 \\
\hline $\begin{array}{l}\text { We care for fellow } \\
\text { employees who are } \\
\text { struggling }\end{array}$ & 146 & .707 & -.033 & .087 & -.058 & -.062 \\
\hline $\begin{array}{l}\text { We provide emotional } \\
\text { support to each other }\end{array}$ & -.002 & .696 & .129 & .005 & .019 & .064 \\
\hline $\begin{array}{l}\text { We show compassion } \\
\text { for each other. }\end{array}$ & .066 & .606 & .127 & 102 & -.041 & -.019 \\
\hline $\begin{array}{l}\text { We build strong } \\
\text { interpersonal } \\
\text { relationships }\end{array}$ & .057 & .592 & .109 & .052 & -.042 & .074 \\
\hline $\begin{array}{l}\text { We show kindness to } \\
\text { one another }\end{array}$ & 297 & .427 & .107 & 175 & -.151 & -.098 \\
\hline $\begin{array}{l}\text { We honor one another's } \\
\text { talents }\end{array}$ & .081 & .402 & -.006 & .184 & -.041 & .127 \\
\hline \multicolumn{7}{|l|}{ Caring } \\
\hline $\begin{array}{l}\text { We are interested in } \\
\text { each other. }\end{array}$ & .005 & .067 & .829 & .072 & .041 & -.008 \\
\hline $\begin{array}{l}\text { We think of each other } \\
\text { as friends }\end{array}$ & .008 & .086 & .812 & .034 & .004 & -.006 \\
\hline $\begin{array}{l}\text { We genuinely care } \\
\text { about each other }\end{array}$ & .048 & .164 & .770 & .005 & .049 & -.022 \\
\hline $\begin{array}{l}\text { We are responsive to } \\
\text { each other. }\end{array}$ & .006 & .007 & .510 & .066 & .174 & -.051 \\
\hline \multicolumn{7}{|l|}{ Meaning } \\
\hline $\begin{array}{l}\text { We are being elevated } \\
\text { by our work }\end{array}$ & -.106 & -.075 & -.023 & -.596 & .145 & .109 \\
\hline $\begin{array}{l}\text { We are being renewed } \\
\text { by what we do }\end{array}$ & -.094 & -.172 & -.139 & -.562 & .230 & .062 \\
\hline $\begin{array}{l}\text { We feel that our work } \\
\text { has profound meaning }\end{array}$ & -.203 & -.124 & -.084 & -.562 & -.086 & .095 \\
\hline $\begin{array}{l}\text { We find our work } \\
\text { motivating }\end{array}$ & -.055 & -.155 & -.087 & -.554 & .052 & .007 \\
\hline $\begin{array}{l}\text { We see the larger } \\
\text { purpose in our work }\end{array}$ & -.210 & -.196 & -.149 & -.230 & -.103 & .094 \\
\hline \multicolumn{7}{|l|}{ Inspiration } \\
\hline $\begin{array}{l}\text { We share enthusiasm } \\
\text { with one another }\end{array}$ & -.085 & -.050 & .048 & -.055 & .692 & .010 \\
\hline We inspire each other & -.089 & -.090 & .152 & -.109 & .626 & .002 \\
\hline $\begin{array}{l}\text { We communicate the } \\
\text { good we see in one }\end{array}$ & -.179 & -.007 & .049 & .114 & .385 & -.071 \\
\hline
\end{tabular}




\begin{tabular}{lcccccc}
\hline & $\begin{array}{c}\text { Dignity \& } \\
\text { Respect }\end{array}$ & Support & Caring & Meaning & Inspiration Forgiveness \\
\hline $\begin{array}{l}\text { another. } \\
\text { Forgiveness }\end{array}$ & & & & & & \\
\hline $\begin{array}{l}\text { We do not blame one } \\
\text { other when mistakes } \\
\text { are made }\end{array}$ & .063 & -.071 & .050 & .081 & .074 & $\mathbf{- . 7 8 3}$ \\
$\begin{array}{l}\text { We correct errors } \\
\text { without placing blame. }\end{array}$ & -.015 & -.015 & .000 & .059 & .034 & $\mathbf{- . 7 6 4}$ \\
\hline We forgive mistakes & -.003 & .080 & -.010 & .103 & -.088 & $\mathbf{- . 6 0 5}$ \\
\hline
\end{tabular}

Appendix A: Rotated Components Matrix from Factor Analysis from Nursing Units - 2005

\begin{tabular}{|c|c|c|c|c|c|c|}
\hline & $\begin{array}{l}\text { Dignity \& } \\
\text { Respect }\end{array}$ & Caring & Support & Inspiration & Forgiveness & Meaning \\
\hline \multicolumn{7}{|l|}{ Dignity \& Respect } \\
\hline $\begin{array}{l}\text { We treat each other with } \\
\text { respect }\end{array}$ & .801 & .009 & .080 & .064 & .043 & -.119 \\
\hline $\begin{array}{l}\text { We foster dignity in } \\
\text { each other }\end{array}$ & .752 & .076 & .097 & -.026 & .047 & .013 \\
\hline We trust one another & .721 & -.011 & .076 & .023 & -.003 & -.007 \\
\hline $\begin{array}{l}\text { We display confidence } \\
\text { in one another }\end{array}$ & .633 & .095 & .002 & -.104 & .041 & -.030 \\
\hline $\begin{array}{l}\text { We show appreciation } \\
\text { for one another }\end{array}$ & .632 & -.058 & .143 & -.070 & .018 & -.018 \\
\hline $\begin{array}{l}\text { We demonstrate } \\
\text { integrity }\end{array}$ & .575 & -.050 & .139 & .064 & -.060 & -.010 \\
\hline $\begin{array}{l}\text { We express gratitude to } \\
\text { each other }\end{array}$ & .368 & -.078 & .181 & -.055 & .134 & -.041 \\
\hline \multicolumn{7}{|l|}{ Caring } \\
\hline $\begin{array}{l}\text { We are interested in } \\
\text { each other. }\end{array}$ & .066 & .869 & .070 & .014 & .054 & -.043 \\
\hline $\begin{array}{l}\text { We think of each other } \\
\text { as friends }\end{array}$ & . 009 & .856 & .030 & .068 & .033 & -.043 \\
\hline $\begin{array}{l}\text { We genuinely care } \\
\text { about each other }\end{array}$ & -.017 & .778 & 151 & .048 & -.077 & .024 \\
\hline $\begin{array}{l}\text { We are responsive to } \\
\text { each other. }\end{array}$ & -.036 & .511 & .153 & -.002 & -.126 & -.034 \\
\hline \multicolumn{7}{|l|}{ Support } \\
\hline $\begin{array}{l}\text { We help people who are } \\
\text { facing difficulty }\end{array}$ & .083 & .150 & .782 & -.104 & -.029 & -.012 \\
\hline $\begin{array}{l}\text { We provide emotional } \\
\text { support to each other }\end{array}$ & .059 & .195 & .771 & -.045 & -.006 & -.045 \\
\hline $\begin{array}{l}\text { We honor one another's } \\
\text { talents }\end{array}$ & 1119 & -.083 & 644 & .034 & -.012 & .002 \\
\hline $\begin{array}{l}\text { We show compassion } \\
\text { for each other. }\end{array}$ & 277 & .122 & .537 & .060 & -.025 & .091 \\
\hline $\begin{array}{l}\text { We care for fellow } \\
\text { employees who are } \\
\text { struggling }\end{array}$ & .183 & .113 & .444 & .051 & -.032 & -.081 \\
\hline $\begin{array}{l}\text { We show kindness to } \\
\text { one another }\end{array}$ & 293 & .020 & .416 & -.188 & 124 & .011 \\
\hline $\begin{array}{l}\text { We build strong } \\
\text { interpersonal } \\
\text { relationships }\end{array}$ & 198 & .119 & .344 & -.058 & 103 & -.110 \\
\hline \multicolumn{7}{|l|}{ Inspiration } \\
\hline $\begin{array}{l}\text { We share enthusiasm } \\
\text { with one another }\end{array}$ & -.066 & .108 & -.087 & .678 & .098 & -.016 \\
\hline We inspire each other & -.062 & .139 & -.041 & .508 & -.017 & .025 \\
\hline We communicate the & .049 & -.097 & .170 & .350 & -.040 & -.162 \\
\hline
\end{tabular}




\begin{tabular}{|c|c|c|c|c|c|c|}
\hline & $\begin{array}{c}\text { Dignity \& } \\
\text { Respect }\end{array}$ & Caring & Support & Inspiration & Forgiveness & Meaning \\
\hline \multicolumn{7}{|l|}{$\begin{array}{l}\text { good we see in one } \\
\text { another. }\end{array}$} \\
\hline \multicolumn{7}{|l|}{ Forgiveness } \\
\hline $\begin{array}{l}\text { We do not blame one } \\
\text { other when mistakes are } \\
\text { made }\end{array}$ & -.041 & -.006 & -.003 & .019 & -.771 & -.046 \\
\hline $\begin{array}{l}\text { We correct errors } \\
\text { without placing blame. }\end{array}$ & -.077 & .037 & .011 & -.071 & -.734 & .052 \\
\hline We forgive mistakes & -.028 & .029 & .083 & -.016 & -.602 & .016 \\
\hline \multicolumn{7}{|l|}{ Meaning } \\
\hline $\begin{array}{l}\text { We see the larger } \\
\text { purpose in our work }\end{array}$ & -.154 & -.108 & .014 & -.093 & -.021 & .693 \\
\hline $\begin{array}{l}\text { We feel that our work } \\
\text { has profound meaning }\end{array}$ & .018 & .012 & -.043 & .020 & -.005 & .689 \\
\hline $\begin{array}{l}\text { We find our work } \\
\text { motivating }\end{array}$ & -.152 & .034 & -.146 & .207 & .017 & .404 \\
\hline $\begin{array}{l}\text { We are being renewed } \\
\text { by what we do }\end{array}$ & -.069 & -.077 & -.081 & .056 & .001 & .179 \\
\hline $\begin{array}{l}\text { We are being elevated } \\
\text { by our work }\end{array}$ & -.085 & -.114 & -.063 & .094 & -.051 & .001 \\
\hline
\end{tabular}

Appendix A: Rotated Components Matrix from Factor Analysis from Nursing Units - 2007

\begin{tabular}{lcccccc}
\hline & $\begin{array}{c}\text { Dignity \& } \\
\text { Respect }\end{array}$ & Support & Caring & Meaning & Forgiveness & Inspiration \\
\hline $\begin{array}{l}\text { Dignity \& Respect } \\
\text { We treat each other with }\end{array}$ & .800 & .017 & -.041 & -.071 & -.063 & .038 \\
\hline $\begin{array}{l}\text { respect } \\
\text { We demonstrate }\end{array}$ & .686 & .037 & -.017 & -.162 & -.010 & -.038 \\
\hline $\begin{array}{l}\text { integrity } \\
\text { We express gratitude to } \\
\text { each other }\end{array}$ & .682 & .098 & -.056 & .002 & .004 & -.084 \\
\hline $\begin{array}{l}\text { We foster dignity in } \\
\text { each other }\end{array}$ & .641 & -.020 & -.053 & -.064 & .074 & -.013 \\
\hline $\begin{array}{l}\text { We show appreciation } \\
\text { for one another }\end{array}$ & .608 & -.057 & -.110 & -.051 & .083 & -.046 \\
\hline $\begin{array}{l}\text { We trust one another } \\
\text { We display confidence }\end{array}$ & .597 & .045 & .131 & -.067 & .041 & .046 \\
\hline $\begin{array}{l}\text { in one another } \\
\text { Support }\end{array}$ & .515 & -.114 & -.056 & .018 & .010 & -.149 \\
\hline $\begin{array}{l}\text { We help people who are } \\
\text { facing difficulty }\end{array}$ & -.020 & .791 & .107 & -.058 & -.055 & -.092 \\
\hline $\begin{array}{l}\text { We care for fellow } \\
\text { employees who are } \\
\text { struggling }\end{array}$ & .049 & .739 & -.036 & -.152 & -.007 & -.057 \\
\hline $\begin{array}{l}\text { We provide emotional } \\
\text { support to each other }\end{array}$ & .019 & .691 & .161 & -.085 & .018 & .034 \\
\hline $\begin{array}{l}\text { We honor one another's } \\
\text { talents }\end{array}$ & .011 & .469 & .064 & -.009 & .276 & .009 \\
\hline $\begin{array}{l}\text { We show compassion } \\
\text { for each other. }\end{array}$ & .185 & .432 & .040 & .007 & .019 & .087 \\
\hline $\begin{array}{l}\text { We show kindness to } \\
\text { one another }\end{array}$ & .366 & .380 & -.006 & .078 & .006 & -.003 \\
\hline $\begin{array}{l}\text { We build strong } \\
\text { interpersonal } \\
\text { relationships }\end{array}$ & -.056 & .319 & -.008 & .041 & .125 & .051 \\
\hline $\begin{array}{l}\text { Caring } \\
\text { We are interested in }\end{array}$ &. .032 & .048 & .844 & -.053 & .017 & -.030 \\
\hline
\end{tabular}




\begin{tabular}{|c|c|c|c|c|c|c|}
\hline & $\begin{array}{c}\text { Dignity \& } \\
\text { Respect }\end{array}$ & Support & Caring & Meaning & Forgiveness & Inspiration \\
\hline \multicolumn{7}{|l|}{ each other. } \\
\hline $\begin{array}{l}\text { We think of each other } \\
\text { as friends }\end{array}$ & -.102 & .031 & .780 & -.059 & .112 & .097 \\
\hline $\begin{array}{l}\text { We genuinely care } \\
\text { about each other }\end{array}$ & -.008 & .110 & .724 & -.041 & -.030 & .012 \\
\hline $\begin{array}{l}\text { We are responsive to } \\
\text { each other. }\end{array}$ & .070 & .066 & .583 & .074 & -.028 & .022 \\
\hline \multicolumn{7}{|l|}{ Meaning } \\
\hline $\begin{array}{l}\text { We are being renewed } \\
\text { by what we do }\end{array}$ & -.093 & -.092 & -.028 & .718 & -.010 & .169 \\
\hline $\begin{array}{l}\text { We are being elevated } \\
\text { by our work }\end{array}$ & -.153 & -.099 & -.086 & .692 & .049 & -.016 \\
\hline $\begin{array}{l}\text { We find our work } \\
\text { motivating }\end{array}$ & -.100 & -.141 & -.032 & .540 & -.026 & -.017 \\
\hline $\begin{array}{l}\text { We see the larger } \\
\text { purpose in our work }\end{array}$ & -.173 & -.008 & -.093 & 124 & .065 & .036 \\
\hline $\begin{array}{l}\text { We feel that our work } \\
\text { has profound meaning }\end{array}$ & .021 & .013 & -.169 & 101 & 102 & .010 \\
\hline \multicolumn{7}{|l|}{ Forgiveness } \\
\hline $\begin{array}{l}\text { We correct errors } \\
\text { without placing blame. }\end{array}$ & -.016 & .007 & -.083 & .015 & -.781 & -.095 \\
\hline $\begin{array}{l}\text { We do not blame one } \\
\text { other when mistakes are } \\
\text { made }\end{array}$ & -.030 & -.094 & -.081 & .086 & -.770 & .084 \\
\hline We forgive mistakes & -.016 & .089 & .073 & -.139 & -.714 & -.021 \\
\hline \multicolumn{7}{|l|}{ Inspiration } \\
\hline $\begin{array}{l}\text { We share enthusiasm } \\
\text { with one another }\end{array}$ & -.189 & -.046 & .108 & -.084 & .045 & .549 \\
\hline We inspire each other & -.138 & -.013 & .105 & .150 & .079 & .425 \\
\hline $\begin{array}{l}\text { We communicate the } \\
\text { good we see in one } \\
\text { another. }\end{array}$ & -.037 & -.024 & .023 & .098 & -.068 & .061 \\
\hline
\end{tabular}



Appendix B: Names of Business Units in the Financial Services Company in Study 1 and Units
in the Comprehensive Health Care Organization in Study 2

\section{STUDY 1}

[01] Senior Leadership Team

[02] Analyst \& PMO

[03] DC Recordkeeping

[04] DB Recordkeeping

[05] E-Client Delivery

[06] GP and Financial Systems

[07] Business Delivery and Quality Assurance

[08] Process and Metrics

[09] Consulting \& Facilities

[10] Learning \& Leadership Development

[11] Risk Management

[12] Strategic Planning \& Development

[13] Personal Retirement Services

[14] Retirement Income

[15] Stable Value

[16] Payout Annuity

[17] Emerging Corporate Segment

[18] Core/Large Segment

[19] Tax-Exempt Segment

[20] Business Finance

[21] Sales Support Operations

[22] Corporate Sales and Channel Management

[23] Tax-Exempt/Governmental Sales

[24] Product \& Advisory Services

[25] Marketing

[26] Communications \& Education

[27] Business Initiative Development \& Delivery and Client Exp

[28] Core/Large \& Tax-Exempt Client Consulting

[29] Emerging Corporate Client Consulting

[30] Participant Services Center

[31] New Business

[32] DB Operations

[33] DC Operations

[34] Plan Technical Services

[35] Financial Control

[36] Annuity Operations

[37] Strategy/Six Sigma and Client Participant Integration/SWAT

[38] Finance

[39] Legal

[40] Compliance

\section{STUDY 2}

Trauma Burn
4A
4BC
4D North
4D South
5A
5B
5C
5 - SICU
6 A
6 B
6 C
6 D - CCMU
7A
7C
7D - CICU
8A
8B
8C
9 C
Women's Birthing Center
Holden
CH 5 PICU
CH 5E
CH 5W
CH 5 - PCTU
Experience CH 6 - PCTU
CH CAPH
CH 6
CH 7
B1 - Emergency Room

Trauma Burn

$4 \mathrm{BC}$

4D South

$5 A$

5 - SICU

$6 \mathrm{C}$

$6 \mathrm{D}-\mathrm{CCMU}$

7D - CICU

$8 \mathrm{C}$

9C

Holden

CH 5 PICU

$\mathrm{CH} 5 \mathrm{~W}$ 
Appendix C: Financial Performance Data for the Six P\&L Business Units in Financial Services-Percent Variation from Target (Rating)

\begin{tabular}{|c|c|c|c|c|c|c|c|}
\hline & $\begin{array}{c}\text { Total } \\
\text { Business }\end{array}$ & $\begin{array}{c}\text { Business } \\
\text { Unit } 1\end{array}$ & $\begin{array}{c}\text { Business } \\
\text { Unit } 2\end{array}$ & $\begin{array}{c}\text { Business } \\
\text { Unit } 3\end{array}$ & $\begin{array}{c}\text { Business } \\
\text { Unit } 4\end{array}$ & $\begin{array}{c}\text { Business } \\
\text { Unit } 5\end{array}$ & $\begin{array}{c}\text { Business } \\
\text { Unit } 6\end{array}$ \\
\hline Assets & $\begin{array}{c}0.8 \% \\
(3)\end{array}$ & $\begin{array}{c}1.5 \% \\
(3)\end{array}$ & $\begin{array}{c}1.1 \% \\
(3)\end{array}$ & $\begin{array}{c}-0.5 \% \\
(2)\end{array}$ & $\begin{array}{c}2.7 \% \\
(4)\end{array}$ & $\begin{array}{c}-0.3 \% \\
(3)\end{array}$ & $\begin{array}{c}9.9 \% \\
(4)\end{array}$ \\
\hline Sales & $\begin{array}{l}6.8 \% \\
(3)\end{array}$ & $\begin{array}{c}51.4 \% \\
(4)\end{array}$ & $\begin{array}{c}-8.3 \% \\
(3)\end{array}$ & $\begin{array}{c}-22.7 \% \\
(3)\end{array}$ & $\begin{array}{c}-1.3 \% \\
(3)\end{array}$ & $\begin{array}{c}0.8 \% \\
(3)\end{array}$ & $\begin{array}{c}79.8 \% \\
(4)\end{array}$ \\
\hline Cash-Outs & $\begin{array}{c}3.2 \% \\
(3)\end{array}$ & $\begin{array}{c}-15.6 \% \\
(2)\end{array}$ & $\begin{array}{c}13.7 \% \\
\text { (3) }\end{array}$ & $\begin{array}{c}25.7 \% \\
(4)\end{array}$ & $\begin{array}{c}-6.1 \% \\
(3)\end{array}$ & $\begin{array}{c}16.9 \% \\
(3)\end{array}$ & $\mathrm{N} / \mathrm{A}$ \\
\hline Cash Flow & $\begin{array}{c}-352.6 \\
(3)\end{array}$ & $\begin{array}{c}-293.1 \% \\
\text { (3) }\end{array}$ & $\begin{array}{c}-98.8 \% \\
\text { (3) }\end{array}$ & $\begin{array}{c}1066.3 \% \\
(4)\end{array}$ & $\mathrm{N} / \mathrm{A}$ & $\mathrm{N} / \mathrm{A}$ & $\begin{array}{c}-1.5 \% \\
(3)\end{array}$ \\
\hline Revenue & $\begin{array}{c}6.8 \% \\
(3)\end{array}$ & $\begin{array}{c}4.4 \% \\
(3)\end{array}$ & $\begin{array}{c}3.9 \% \\
(3)\end{array}$ & $\begin{array}{c}-1.2 \% \\
(2) \\
\end{array}$ & $\begin{array}{c}24.2 \% \\
(4)\end{array}$ & $\begin{array}{c}20.4 \% \\
(3)\end{array}$ & $\begin{array}{c}20.1 \% \\
(3)\end{array}$ \\
\hline Expenses & $\begin{array}{c}-4.8 \% \\
(3)\end{array}$ & $\begin{array}{c}-9.3 \% \\
(2)\end{array}$ & $\begin{array}{c}-4.6 \% \\
(3)\end{array}$ & $\begin{array}{c}-3.8 \% \\
(3)\end{array}$ & $\begin{array}{c}8.7 \% \\
(4)\end{array}$ & $\begin{array}{c}2.5 \% \\
(3)\end{array}$ & $\begin{array}{c}0.1 \% \\
(3)\end{array}$ \\
\hline AOI & $\begin{array}{l}9.2 \% \\
\text { (3) }\end{array}$ & $\begin{array}{c}-3.0 \% \\
(3)\end{array}$ & $\begin{array}{l}0.8 \% \\
(3)\end{array}$ & $\begin{array}{c}-6.5 \% \\
(3)\end{array}$ & $\begin{array}{c}35.7 \% \\
(4)\end{array}$ & $\begin{array}{c}27.9 \% \\
\text { (3) }\end{array}$ & $\begin{array}{c}2008.2 \% \\
\text { (4) }\end{array}$ \\
\hline
\end{tabular}




\section{References}

Adler, P.S. and Kwon, S. (2002) "Social capital: Prospects for a new concept." Academy of Management Review, 27: 17-40.

Alderfer, C. P. (1966). An Intergroup Perspective on Group Dynamics. In Lorsch, J. (Ed.), Handbook of Organizational Behavior. Englewood Cliffs, NJ: Prentice-Hall.

Andersson, L. M., Giacalone, R. A., and Jurkiewicz, C. L. (2007). On the relationship of hope and gratitude to corporate social responsibility. Journal of Business Ethics, 70:401-409.

Aristotle, Metaphysics XII, 7, 3-4.

Bagozzi, R. P. (2003) "Positive and negative emotions in organizations." In Cameron, K.S., Dutton, J.E., and Quinn, R.E. (Eds.), Positive Organizational Scholarship: Foundations of a New Discipline (pp. 176-193). San Francisco: Berrett-Koehler.

Baker, W. (2000) Achieving Success Through Social Capital. San Francisco: Jossey-Bass.

Baker, W., Cross, R., \& Wooten, M. (2003). "Positive organizational network analysis and energizing relationships." In Cameron, K.S., Dutton, J.E., and Quinn, R.E. (Eds.), Positive Organizational Scholarship: Foundations of a New Discipline (pp. 328-342). San Francisco: Berrett-Koehler.

Baker, W.B. and Bunderson, R. (2005) "Zingerman's community of businesses." Case, Center for Positive Organizational Scholarship, University of Michigan.

Baldassare, M., Rosenfield, S., and Rook, K.S. (1984) "The types of social relations predicting elderly well-being." Research on Aging, 6: 549-559.

Bateman, T. and Porath, C. (2003) "Transcendent motivation." In Cameron, K.S., Dutton, J.E., and Quinn, R.E. (2003) Positive Organizational Scholarship. (pages 122-137) San Francisco: Berrett Koehler.

Baumeister, R. F., Bratslavsky, E., Finkenauer, C., Vohs, K. D. (2001). "Bad is stronger than good." Review of General Psychology, 5: 323-370.

Becker, E. (1973). The Denial of Death. New York: Free Press.

Bless, H., Hamiliton, D. L., \& Mackie, D. M. (1992). Mood effects on the organization of person information. European Journal of Social Psychology, 22, 497-509.

Bono, J. E. and llies, R. (2006). "Charisma, positive emotion and mood contagion." Leadership Quarterly, 17:317-334.

Brickman, P., Coates, D., \& Janoff-Bulman, R. (1978). Lottery winners and accident victims: Is happiness relative? Journal of Personality and Social Psychology, 36: 917-927.

Bright, D.S. (2006) "Forgiveness as an attribute of leadership." In Hess, E.D. and Cameron, K.S. (Eds.) Leading with Values: Positivity, Virtue, and High Performance. Cambridge: Cambridge University Press.

Bright, D.S., Cameron, K.S., and Caza, A. (2006) "The amplifying and buffering effects of virtuousness in downsized organizations." Journal of Business Ethics, 64: 249-269.

Brown, D.E. (1991) Human Universals. New York: McGraw Hill.

Burrough, B. and Helyar, J. (1990) Barbarians at the Gate. New York: Harper \& Row.

Cameron, K. S. (2003) "Organizational virtuousness and performance." In K. S. Cameron, J. Dutton \& R. E. Quinn (Eds.), Positive Organizational Scholarship (pp. 48-65). San Francisco: Berrett-Koehler.

Cameron, K.S. (2008a) "Paradox in positive organizational change." Journal of Applied Behavioral Science, 44: 7-24.

Cameron (2008b) Positive Leadership. San Francisco: Berrett Koehler.

Cameron, K. S., Bright, D., \& Caza, A. (2004) "Exploring the relationships between organizational virtuousness and performance." American Behavioral Scientist, 4: 766790.

Cameron, K. S., Dutton, J. E., \& Quinn, R. E. (2003). Positive Organizational Scholarship. San Francisco: Berrett-Koehler. 
Cameron, K.S. and Lavine, M. (2006) Making the Impossible Possible: Leading Extraordinary Performance-The Rocky Flats Story. San Francisco: Berrett Koehler.

Carson, J. and Barling, J. (2008) "Work and well-being." In Barling, J. and Cooper C.L. The Sage Handbook of Organizational Behavior (Chapter 35, pp. 675-692) Los Angeles: Sage.

Caza, A. and Cameron, K.S. (2008) "Positive organizational scholarship: What does it achieve?" In Cooper, C.L. and Clegg, S. (Eds.) Handbook of Macro-Organizational Behavior. (pages 99-116) New York: Sage.

Christakis, N.A. and Fowler, J.H. (2009) Connected: the Surprising Power of our Social Networks and How They Shape our Lives. New York: NY Little, Brown and Co.Chun, R. (2005) "Ethical character and virtue of organizations: An empirical assessment and strategic implications." Journal of Business Ethics, 57: 269-284.

Clifton, D. O. and Harter, J.K. (2003). "Investing in strengths." In Cameron, K. S., Dutton, J. E., and Quinn, R. E., (Eds.) Positive Organizational Scholarship: Foundations of a New Discipline, (pages 111-121) San Francisco: Berrett-Koehler.

Cohen S. (2003) "The social environment and susceptibility to infectious disease." Conference on The Role of Environmental Influences on Health and Performance: From Organism to Organization. University of Michigan, September.

Coleman, J.S. (1998) "Social capital in the creation of human capital." American Journal of Sociology, 94 (Supplement): S95-S120.

Coleman, L. M., Jussim, L., \& Abraham, J. (1987). "Students' reactions to teacher evaluations: The unique impact of negative feedback." Journal of Applied Social Psychology, 17:1051-1070.

Comte-Sponville, A. (2001) A Small Treatise of the Great Virtues. (C. Temerson, Translator). New York: Metropolitan Books.

Cooper, H. Okamura, L., and Gurka, V. (1992) "Social activity and subjective well-being." Personality and Individual Differences, 13: 573-583.

Cooperrider, D.L. and Srivastva, S. (1987) "Appreciative inquiry in organizational life.". Research in Organizational Change and Development, 1: 129-169.

Crede, M., Chernyshenko, O.S., Stara, S., and Dalal, R.S. (2005) "The relationship between well-being and job performance." (Manuscript submitted for publication.

D'Amato, M. R., \& Jagoda, H. (1962). "Effect of early exposure to photic stimulation on brightness discrimination and exploratory behavior." Journal of Genetic Psychology, 101: 267-\&.

Dienstbier. R. A. and Zillig, L.M. P. (2002) "Toughness." In C.R. Snyder \& S. J. Lopez (Eds.) Handbook of Positive Psychology, (pp. 515-527) New York: Oxford University Press.

Donovan, M.A. (2000) Cognitive, Affective, and Satisfaction Variables as Predictors of Organizational Behaviors: A Structural Equation Modeling Examination of Alternative Models. Dissertation Abstracts International, 60 (9-B), 4943. (UMI \#AA19944835).

Dreben, E. K., Fiske, S. T., \& Hastie, R. (1979) "The independence of evaluative and item information: Impression and recall order effects in behavior based impression formation." Journal of Personality and Social Psychology, 37: 1758-1768.

Drexelius, J. (1627). The Heliotropium, or Conformity of the Human Will to the Divine (R. N. I. Translated by Shutte, Trans.). New York: The Devin-Adair Company.

Dutton, J.E. (2003) Energize Your Workplace." San Francisco: Jossey-Bass.

Dutton, J.E., Frost, P.J., Worline, M.C., Lilius, J.M., and Kanov, J.M. (2002) "Leading in times of trauma." Harvard Business Review, January: 54-61.

Dutton, J. E., Worline, M. C., Frost, P. J., and Lilius, J. (2006) "Explaining compassion organizing." Administrative Science Quarterly, 51: 59-96.

Dutton, J. E., \& Glynn, M. (2007). "Positive organizational scholarship." In C. Cooper \& J. Barling (Eds.), Handbook of Organizational Behavior. Thousand Oaks, CA: Sage. 
Dutton, J. E., \& Sonenshein, S. (2007). "Positive organizational scholarship." In Lopez, S. and Beauchamps, A. (Eds.), Encyclopedia of Positive Psychology. Malden, MA: Blackwell Publishing.

Emmons, R.A. (2007) Thanks. New York: Houghton Mifflin.

Erdelyi, E.H. (1974) "A new look at a New Look: Perceptual defense and vigilance." Psychological Review, 81: 1-25.

Erhard-Seibold, E.V. (1937) "The heliotrope tradition." Orisis, 3: 22-46.

Feldman, M. S., \& Khademian, A. M. (2003). "Empowerment and cascading vitality." In K. S. Cameron, J. E. Dutton \& R. E. Quinn (Eds.), Positive Organizational Scholarship: Foundations of a New Discipline (pp. 343-358). San Francisco: Berrett-Koehler.

Fineman, S. (1996) "Emotion and Organizing." In Clegg, S.R., Hardy, C., and Nord, W.R. (Eds.) The Handbook of Organizational Studies. (pp. 543-564) London: Sage.

Fineman, S. (2006) "On being positive: Concerns and counterpoints." Academy of Management Review, 31: 270-291.

Foster, J.B., Hebl, M.R., West, M., and Dawson, J. (2004) "Setting the tone for organizational success: The impact of CEO affect on organizational climate and firm-level outcomes." Paper presented at the $17^{\text {th }}$ annual meeting of the Society for Industrial and Organizational Psychology, Toronto, Canada.

Fredrickson, B. L. (1998) "What good are positive emotions?" Review of General Psychology, 2: 300-319.

Fredrickson, B.L. (2009) Positivity. New York: Crown.

Fredrickson, B. L. and Joiner, (2002) "Positive emotions trigger upward spirals toward emotional well-being." American Psychologist, 13: 172-175.

Fredrickson, B.L. (2003) "Positive emotions and upward spirals in organizations." In Cameron, K. S., Dutton, J. E., and Quinn, R. E., (Eds.) Positive Organizational Scholarship: Foundations of a New Discipline, (pages 163-175) San Francisco: Berrett-Koehler.

Fredrickson, B. L., \& Losada, M. F. (2005) "Positive affect and the complex dynamics of human flourishing." American Psychologist, 60: 678-686.

Fry, L. W., Vitucci, S., and Cedillo, M. (2005) "Spiritual leadership and army transformation: Theory, measurement, and establishing a baseline." Leadership Quarterly, 16:835-862.

Gary S. Becker (1964, 1993, 3rd ed.). Human Capital: A Theoretical and Empirical Analysis, with Special Reference to Education. Chicago, University of Chicago Press.

George, J.M. (1995) "Leader positive mood and group performance: The case of customer service." Journal of Applied Social Psychology, 25: 778-794.

George, J.M. (1998) "Salesperson mood at work: Implications for helping customers. Journal of Personal Selling and Sales Management, 18: 23-30.

George, J. M. (2004). Book review of "positive organizational scholarship: Foundations of a new discipline". Administrative Science Quarterly, 49(2), 325-330.

Giacalone, R. A., Paul, K., and Jurkiewicz, C. L. (2005). "A preliminary investigation into the role of positive psychology in consumer sensitivity to corporate social performance." Journal of Business Ethics, 58:295-305.

Gittell, J.H. (2000) "Organizing work to support relational coordination." International Journal of Human Resource Management, 11: 517-539.

Gittell, J.H. (2001) "Supervisory span, relational coordination, and flight departure performance: A reassessment of post-bureaucracy theory." Organization Science, 12: 467-482.

Gittell, J.H., Cameron, K.S., Lim, S. and Rivas, V. (2006) "Relationships, layoffs, and organizational resilience." Journal of Applied Behavioral Science, 42: 300-328.

Gladwell, M. (2002) The Tipping Point: How Little Things Make a Big Difference. Boston: Back Bay Publishers.

Gouldner, A. (1960). "The norm of reciprocity: A preliminary statement." American Sociological Review, 25, 161-179. 
Grant, A.M., Campbell, E.M., Chen, G., Cottone, K., Lapedis, D., and Lee, K. (2007) "Impact and the art of motivation maintenance: The effects of contact with beneficiaries on persistent behavior." Organizational Behavior and Decision Processes,

Hackman, J.R. (2008) "The perils of positivity." Journal of Organizational Behavior, 30: 309-319.

Hamilton, D. L., \& Huffman, L. J. (1971). "Generality of impression formation processes for evaluative and non-evaluative judgments." Journal of Personality and Social Psychology, 20: 200-207.

Harter, J. K., Schmidt, F.L. and Keyes, C.L.M. (2002) "Well-being in the workplace and its relationship to business outcomes: A review of the Gallup studies." In Keyes, C.L. and Haidt, J. (Eds.) Flourishing: The Positive Person and the Group Life. (pages 205-224) Washington D.C.: American Psychological Association.

Hatch, M.J. (1999) "Exploring the empty spaces of organizing: How improvisational jazz helps redescribe organizational structure." Organizational Studies, 20: 75-100.

Hess, E.D. and Cameron, K.S. (2006) Leading with Values: Positivity, Virtues, and High Performance. New York: Cambridge University Press.

Ilies, R., Nahrgang, J. D., and Morgeson, F. O. (2007). "Leader-member exchange and citizenship behaviors: A meta-analysis." Journal of Applied Psychology, 92: 269-277.

Jensen, Michael C. (2002) "Value maximization, stakeholder theory, and the corporate objective function." Business Ethics Quarterly, 12: 235-256.

Jundt, D. and Hinsz, V.B. (2001) "Are happier workers more productive workers? The impact of mood on self-set goals, self-efficacy, and task performance." Paper presented at the annual meeting of the American Psychological Association, Chicago.

Kaplan J. (2003) "Status, stress, and atherosclerosis: The role of environment and individual behavior." Conference on The Role of Environmental Influences on Health and Performance: From Organism to Organization. University of Michigan, September.

Kellett, J. B., Humphrey, R. H., and Sleeth, R. G. (2006). "Empathy and the emergence of task and relations leaders." Leadership Quarterly, 17:146-162.

Kiecolt-Glaser, J. (2003) "The effect of environmental factors on health: Wound healing as a model." Conference on The Role of Environmental Influences on Health and Performance: From Organism to Organization. University of Michigan, September.

Klinger, E., Barta, S. G., \& Maxeiner, M. E. (1980) "Motivational correlates of though contecnt frequency and commitment." Journal of Personality and Social Psychology, 39: 12221237.

Kok, B. E. \& Fredrickson, B. L. (2010). Upward spirals of the heart: Autonomic

flexibility, as indexed by vagal tone, reciprocally and prospectively predicts positive emotions and social connectedness. Biological Psychology. DOI 10.1016/j.biopsycho.2010.09.005

Korten, D.C. (2001) When Corporations Rule the World. San Francisco: Berrett Koehler.

Koys, D.J. (2001) "The effects of employee satisfaction, organizational citizenship behavior, and turnover on organizational effectiveness." Personnel Psychology, 54: 101-114.

Krebs, D. (1987) "The challenge of altruism in biology and psychology." In C. Crawford, M. Smith \& D. Krebs (Eds.), Sociobiology and Psychology. Hillsdale, NJ: Lawrence Erlbaum.

Laumann, E. O., Gagnon, J. H., Michael, R. T., \& Michaels, S. (1994). The Social Organization of Sexuality: Sexual Practices in the United States. Chicago: University of Chicago Press.

Laumann, E. O., Paik, A., \& Rosen, R. C. (1999). "Sexual dysfunction in the United States: Prevalence and predictors." Journal of the American Medical Association, 281, 537-544.

Lawrence, P.R. and Nohria, N. (2002) Driven: How Human Nature Shapes Our Choices. San Francisco: Jossey Bass.

Leana, C.R. and Van Buren, H.J. (1999) "Organizational social capital and employment practices." Academy of Management Review, 24: 538-555. 
Losada, M., \& Heaphy, E. (2004) "The role of positivity and connectivity in the performance of business teams - A nonlinear dynamics model." American Behavioral Scientist, 47(6), 740-765.

Luthans, F, Youssef, C.M., and Avolio, B.J. (2007) Psychological Capital: Developing the Human Competitive Edge. New York: Oxford University Press.

Lyubromirsky, S, King, L., and Diener, E. (2005) "The benefits of frequent positive affect: Does happiness lead to success?" Psychological Bulletin, 131: 803-855.

Manne, S. L., Taylor, K. L., Dougherty, J., \& Kemeny, N. (1997) "Supportive and negative responses in the partner relationship: Their association with psychological adjustment among individuals with cancer." Journal of Behavior Medicine, 20: 101-125.

Margolis, J.D. and Walsh, J.P. (2003) "Misery loves companies: Rethinking social initiatives by business." Administrative Science Quarterly, 48: 268-305.

Marotto, M., Roos, J., and Victor, B. (2007) "Collective virtuosity in organizations: A study of peak performance in an orchestra." Journal of Management Studies, 44: 388-413.

Maslow, A. H. (1968). Toward a Psychology of Being. New York: Van Nostrand.

Masten, A.S., Hubbard, J.J., Gest, S.D., Tellegen, A., Garmezy, N., and Ramirez, M. (1999) "Competence in the context of adversity: Pathways to reliance and maladaptation from childhood to late adolescence." Development and Psychopathology, 11: 143-169.

McLean, B. and Elkind, P. (2003) The Smartest Guys in the Room. New York: Penguin.

Merton, R.K. (1968) Social Organization and Social Structure. New York: Free Press.

Mishra, S. (1992) "Leisure activities and life satisfaction in old age: A case study of retired government employees living in urban areas." Activities, Adaptation, and Aging, 16: 7-26.

Moberg, D. (1999) “The Big Five and organizational virtue.” Business Ethics Quarterly, 9: 245272.

Moore, G. and Beadle, R. (2006) "In search of organizational virtue in business: Agents, goods, practices, institutions, and environments." Organization Studies, 27: 369-389.

Mrosovsky, N., \& Kingsmill, S. F. (1985). "How turtles find the sea." Zeitschrift Fur Tierpsychologie-Journal of Comparative Ethology, 67(1-4), 237-256.

Murphy, P.E. (1999) "Character and virtue ethics in international marketing: An agenda for managers, researchers, and educators." Journal of Business Ethics, 18: 107-124.

Nahapiet, J. and Ghoshal, S. (1988) "Social capital, intellectual capital, and the organizational advantage." Academy of Management Review, 23: 242-266.

Nezlek, J. B., \& Gable, L. (1999) "Daily events, day-to-day psychological adjustment, and depressive symptoms."

Peterson, C. and Seligman, M.E.P. (2004) Character Strengths and Virtues. New York: Oxford University Press.

Philips, D.L. (1967) "Mental health status, social participation, and happiness." Journal of Health and Social Behavior, 8: 285-291.

Podsakoff P.M. and Mackenzie, S.B. (1994) "Organizational citizenship behaviors and sales unit effectiveness." Journal of Marketing Research, 31: 351-363.

Podsakoff, P.M., Mackenzie, S.B., Paine, J.B. \& Bachrach, D.G. (2000) "Organizational citizenship behaviors: A critical review of the theoretical and empirical literature and suggestions for future research." Journal of Management, 26: 513-563.

Powley, E.H. and Cameron, K.S. (2006) "Organizational healing: Lived virtuousness amidst organizational crisis." Journal of Management, Spirituality, and Religion, 3: 13-33.

Roberts, L.M. (2006) "Shifting the lens on organizational life: The added value of positive scholarship." Academy of Management Review, 31: 292-305.

Rook, K. S. (1984) "The negative side of social interaction: Impact on psychological well-being." Journal of Personality and Social Psychology, 46: 1097-1108.

Rothbart, M., \& Park, B. (1986) "On the confirmatility and disconfirmability of trait concepts." Journal of Personality and Social Psychology, 50: 131-142. 
Schneider, B., \& Bowen, D.E. (1985). Employee and customer perceptions of service in banks: Replication and extension. Journal of Applied Psychology, 70: 423-433.

Seligman, M.E.P. (1999) “The president's address." American Psychologist, 54: 559-562.

Seligman, M.E.P. (2002) Authentic Happiness. New York: Free Press.

Seligman, M. E.P., Schulman, P., DeRubeis, R.J., and Hollon, S.D. (1999) "The prevention of depression and anxiety." Prevention and Treatment, 2. http://journals.apa.org/prevention/

Seligman, M.E.P., \& Csikszentmihalyi, M. (2000) "Positive psychology: An introduction." American Psychologist, 55: 5-14.

Sethi, R., \& Nicholson, C. Y. (2001) "Structural and contextual correlates of charged behavior in product development teams." Journal of Product Innovation Management, 18: 154-168.

Shanahan, K.J. and Hyman, M.R. (2003) "The development of a virtue ethics scale." Journal of Business Ethics, 42: 197-208.

Sharot, T., Riccardi, A.M., Raio, C.M., and Phelps, E.A. (2007) "Neural mechanisms mediating optimism bias." Nature, 450: 102-106.

Skinner, B.F. (1965) Science and Human Behavior. New York: Free Press.

Skowronski, J. J., \& Carlston, D. E. (1989). "Negativity and extremity biases in impression formation: A review of explanation." Psychological Review, 105: 131-142.

Smith, A. (1776) The Wealth of Nations. London: Methuen \& Company.

Smith, J. C., \& Baker, H. D. (1960) "Conditioning in the Horseshoe Crab." Journal of Comparative and Physiological Psychology, 53: 279-281.

Solomon, R.C. (1992) Ethics and Excellence: Cooperation and Integrity in Business. New York: Oxford University Press.

Solomon, R.C. (1999) A Better Way to Think About Business: How Perspnal Integrity Leads to Corporate Success. Ney York: Oxford University Press.

Spreitzer, G. and Sonenshein, S. (2003) "Positive deviance and extraordinary organizing." In Cameron, K. S., Dutton, J. E., \& Quinn, R. E. (Eds.). Positive Organizational Scholarship : Foundations of a New Discipline (pp. 207-226.). San Francisco, CA: Berrett-Koehler.

Spreitzer, G.M. and Sonenshein, S. (2004) "Toward the construct definition of positive deviance." American Behavioral Scientist, 47: 808-827.

Spreitzer, G., Sutcliffe, K, Dutton, J., Sonenshein, S., and Grant, A.M. (2005) "A socially embedded model of thriving at work." Organization Science, 16: 537-549.

Staw, B.M., L.E. Sandelands, and J.E. Dutton (1981) "Threat-rigidity effects in organizational behavior: A multilevel analysis." Administrative Science Quarterly, 26, pp. 501-24.

Staw, B.M. and Barsade, S.G. (1993) "Affect and managerial performance: A test of the sadderbut wiser versus Happier-and-smarter hypothesis." Administrative Science Quarterly, 38: 304-331.

Staw, B.M., Sutton, R.I. and Relled, L.H. (1994) "Employee positive emotion and favorable outcomes at the workplace." Organization Science, 5: 51-71.

Sun, L. Y., Aryee, S. \& Law, K. S. (2007) "High performance human resources practices, citizenship behavior and organizational performance: A relational perspective." Academy of Management Journal, 50: 558-577.

Sutcliffe, K.M. and Vogus, T.J. (2003) "Organizing for resilience.” In Cameron, K.S., Dutton, J.E., and Quinn, R.E. (Eds.) Positive Organizational Scholarship. (pages 94-110) San Francisco: Berrett-Koehler.

Tutu, D. (1999) No Future Without Forgiveness. New York: Doubleday.

Unkelbach, C., Fiedler, K., Bayer, M., Stegmuller, M. and Danner, D. (2008) "Why positive information is processed faster: The density hypothesis." Journal of Personality and Social Psychology, 95: 36-49. 
Van Katwyk, P.T., Fox, S., Spector, P.E., and Kelloway, E.K. (2000) "Using the job-related affective well-being scale to investigate affective responses to work stressors." Journal of Occupational Health Psychology, 52: 219-230.

Vannette, D. and Cameron, K.S. (2008) "Implementing Positive Organizational Scholarship at Prudential." Case \# . Ross School of Business, University of Michigan. Distributed by the William Davidson Institute.

Veenhoven, R. (2008) "Sociological theories of subjective well-being." In Eid M. and Larsen R. (Eds.) The Science of Subjective Well-Being, (pages 44-61) New York: Guilford Publications.

Walz, S.M. and Niehoff, B.P. (2000) "Organizational citizenship behaviors: Their relationship to organizational effectiveness." Journal of Hospitality and Tourism Research, 24: 301-319.

Wang, C.S., Galinsky, A.D., and Murnighan, J.K. (2009) "Bad drives psychological reactions, but good propels behavior." Psychological Science, 20: 634-644.

Weick, K.E. (1999) The Social Psychology of Organizing. Reading, MA: Addison-Wesley.

Weick, K.E. (2003) "Positive organizing and organizational tragedy." In Cameron, K.S., Dutton, J.E., and Quinn, R.E. (Eds.), Positive Organizational Scholarship: Foundations of a New Discipline (pp. 66-80). San Francisco: Berrett-Koehler.

Weick, K.E., Sutcliffe, K.M., and Obstfeld, D. (1999) "Organizing for high reliability: Processes of collective mindfulness." Research in Organizational Behavior, 21: 81-123.

Wildavsky, A. (1991) Searching for Safety. New Brunswick: Transaction Books.

Worline, M.C., Dutton, J.E., Frost, P.J., Kanov, J., Lilius, J., and Maitlis, S. (2003) "Creating fertile soil: The organizing dynamics of resilience." Working paper, University of Michigan School of Business.

Wright, T.A. and Goodstein, J. (2007) "Character is not dead in management research: A review of individual character and organizational-level virtue." Journal of Management, 33: 928958.

Wrzesniewski, A. (2003) "Finding positive meaning in work." In Cameron, K. S., Dutton, J. E., \& Quinn, R. E. (Eds.). Positive Organizational Scholarship: Foundations of a New Discipline (pp. 296-308.). San Francisco, CA: Berrett-Koehler. 